\title{
Genealogy of the Soyacene: The tropical bonanza of soya bean farming during the Great Acceleration
}

CLAITON MARCIO DA SILVA

Federal University of the Southern Frontier,

UFFS, Chapecó, Brazil

CLAUDIO DE MAJO

Rachel Carson Center for Environment and Society, Ludwigs-Maximilian University, Munich, Germany

\section{Abstract}

This article examines the expansion of soya bean farming in the Latin American Southern Cone, analysing the main historical drives that led to the rise of this Asian-born grain at tropical latitudes. Drawing on the methodological tools of global environmental history, it provides a historical reconstruction of the biotechnological innovations that allowed this expansion and the ecological consequences of this agricultural revolution. After a brief chronology of the grain's introduction at the subtropical latitudes of southern Brazil and Argentina, the article looks at the genetic improvements that have allowed soya bean cultivation to progressively shift towards warmer latitudes since the 1970 s, a process further accelerated by the breeding of transgenic varieties during the 1990s. Finally, it describes the social and ecological issues brought by the tropical bonanza of soya beans. This ongoing process will undoubtedly continue to permeate nutrition regimes and sustainability debates in Latin America and possibly in other parts of the world for years to come.

Keywords: soya bean, Great Acceleration, Southern Cone, transgenic crops, tropics, global deforestation 
Today, soya (Glycine $\max$ (L.) Merrill) constitutes the primary source of vegetal proteins on earth and is an essential element for the industrial production of animal proteins through its highly nutritious oil cake feeds. ${ }^{1}$ About 77 per cent of the soya produced worldwide today is fed to livestock to produce meat and dairy products. Conversely, the remaining 23 per cent goes towards human nutrition (19.2 per cent, as a base for soya products such as tofu, milk and cooking oil) and for industry (3.8 per cent, to make biodiesels and lubricants). ${ }^{2}$ Every year, between September and March, a large part of Latin America's arable land is destined to transgenic soya bean monoculture rather than other edible crops such as rice, wheat or maize. Countries such as Argentina, Bolivia, Brazil, Paraguay, Uruguay, India and Mexico produce more than half of global soya yields. Brazil and Argentina alone yield almost 160 million metric tons (MMT) combined. ${ }^{3}$ Although today soya seems to thrive at tropical latitudes, it originates in different climates. Recent archaeogenetic studies hypothesise simultaneous domestication in northern China, Japan and Korea before 5000 BC. ${ }^{4}$ All these regions share radically different climatic patterns to the tropical regions where soya has become a key crop since the second half of the twentieth century. How could this endemic crop successfully adapt to a climate in which it would have normally succumbed, becoming one of the main foodstuffs on earth?

This article analyses the historical processes that led to the tropicalisation of soya, allowing it to thrive in the warmer planetary latitudes of Latin America. Focusing on the historical period that John R. McNeill and Peter Engelke have defined as the Great Acceleration, we provide a historical overview of the development of soya bean monocultures in the Latin American Southern Cone. ${ }^{5}$ As the data discussed here demonstrate, the implementation of large-scale soya bean farming led to the

\footnotetext{
1 Today's farmed soya (genus Glycine Willd.) is a leguminous plant from the family Fabaceae, subfamily Papilionoideae (to which also belong other renowned nutritive plants such as beans and peas), tribe Phaseoleae, subtribe Glycininae. Within the genus Glycine there are 22 recognised wild perennial species, while only two species belong to the subgenus Soja, which was domesticated in the Far East. Given its high number of proteins (about 40 per cent), carbohydrates ( 30 per cent) and fats ( 20 per cent), soya is a highly nutritive plant that has been historically utilised both for human nutrition and as a source of animal feed. The latter is normally made by the preparation of oil cakes, solid residue by-products created after grinding for oil. See Colin Wringley, Harold Corke and Charles F. Walker, Encyclopaedia of Grain Science, vol. 3 (Cambridge, MA: Elsevier Academic Press, 2004): $136-46$.

2 See Hannah Ritchie, 'Soy', Our World in Data, ourworldindata.org/soy, accessed 28 July 2021.

3 The other half is mainly occupied by the United States and China, among the world's top five producers. For further information, see James Karunga, ' 10 countries with largest soybean production', World Atlas, 30 August 2018, www.worldatlas.com/articles/world-leaders-in-soya-soybean-production-by-country.html, accessed 28 July 2021. Data on the soya production index of each country in the world, updated to 2016, are available at Food and Agriculture Organization (FAO), FOASTAT, Crops, Soybeans (www.fao.org/faostat/en/\#data/QC, accessed 28 July 2021).

4 See for example Xu D. et al., 'Diversity of chloroplast DNA SSRs in wild and cultivated soybeans: Evidence for multiple origins of cultivated soybean', Theoretical and Applied Genetics 105 (2002): 645-53, doi.org/10.1007/ s00122-002-0972-7; and G. A. Lee et al., 'Archaeological soybean (Glycine max) in East Asia: Does size matter?', PLOS ONE 6, no. 11 (2011): e26720, doi.org/10.1371/journal.pone.0026720.

5 John R. McNeill and Peter Engelke, The Great Acceleration. An Environmental History of the Anthropocene since 1945 (Cambridge, MA: Belknap Press of Harvard University Press, 2014): 88-91.
} 
deforestation of several tropical and subtropical bioregions. These include the Brazilian Cerrado, Paraguay's Gran Atlantic Rainforest, the Gran Chaco Plains (Argentina/Paraguay/Bolivia/Brazil), Bolivia's Chiquitano forest, the Uruguayan Campos and the Argentinian Pampas. In addition, intensive animal farming for human consumption incrementally advanced this process, leading to an increase in the production of vegetal oils, biofuels and soya foods. ${ }^{6}$

As soya bean farming became one of the vital productive sectors in Latin America, soya progressively turned into a global commodity, pushing more countries from the Global South to implement monocultures, an ongoing process. Just as global history analyses the 'entanglements and networks that characterise the present moment', this article adopts the term 'Soyacene' to epitomise the connected geographies and frontiers of soya, revealing their interplay and expansion throughout the twentieth century. ${ }^{7}$ Several agronomists, soil scientists and biologists have investigated soya food-chain production and its socio-environmental impacts. Yet a global environmental history of this process is essential to explore the 'turning points' of agronomic innovation and intellectual cooperation that led to the construction of the Soyacene. ${ }^{8}$ Thus, far from writing a comprehensive history of the numerous potential techno-scientific and socioecological entanglements of the Soyacene, this article attempts to draw a general historical outline of one of the most radical agroecological transformations that invested the Southern Hemisphere during the last half-century. Specifically, it focuses on the Latin American Southern Cone, the vast region where the tropical bonanza of soya bean farming began. ${ }^{?}$

6 WWF, The Growth of Soy: Impacts and Solutions (Gland: WWF International, 2014): 15-19, d2ouvy59p0dg6k. cloudfront.net/downloads/wwf_soy_report_final_feb_4_2014.pdf, accessed 28 July 2021.

7 On global environmental history see John R. McNeill and Erin Stewart Mauldin, 'Global environmental history: An introduction', in A Companion to Global Environmental History, ed. John R. McNeill and Erien Stewart Mauldin (Chichester: Wiley-Blackwell, 2012), xv, doi.org/10.1002/9781118279519; on the Soyacene, see Claiton Marcio da Silva and Claudio de Majo, 'Towards the soyacene: Narratives for an environmental history of soybean farming in Latin America’s Southern Cone', Historia Ambiental Latinoamericana y Caribeña (HALAC) 11, no. 1 (2021): 329-56, doi.org/10.32991/2237-2717.2021v11i1.p329-356.

8 See Rubens Onofre Nodari and Miguel Pedro Guerra, 'Avaliação de riscos ambientais de plantas transgênicas', Cadernos de Ciência \& Tecnologia 18, no. 1 (2001): 81-116; Fernando Ferreira Carneiro et al., Dossiê ABRASCO: um alerta sobre os impactos dos agrotóxicos na saúde (Rio de Janeiro: EPSJV; 2015).

9 This large geographical and cultural territory traditionally encompasses the states of Chile, Argentina and Uruguay, all subtropical countries located to the south of the Tropic of the Capricorn that first came together during the Paraguayan War (1864-70). In other instances, this term has also incorporated parts of Paraguay as part of an identitarian conjunction among subtropical Spanish-speaking countries in Latin America. The three southernmost Brazilian states of Rio Grande do Sul, Santa Catarina and Paraná have also been commonly considered as part of this multinational region. Finally, since the early 1990s, a more recent notion of the Southern Cone has also incorporated the tropical lands of Brazil, such as the Amazon and the Cerrado bioregions, as integral parts of a ramified geo-economic entity centred upon monocultures with a common market. For further information, see Amado Luiz Cervo and Mario Rapoport, eds, História do Cone Sul (Rio de Janeiro and Brasília: Revan and UnB, 1998). 


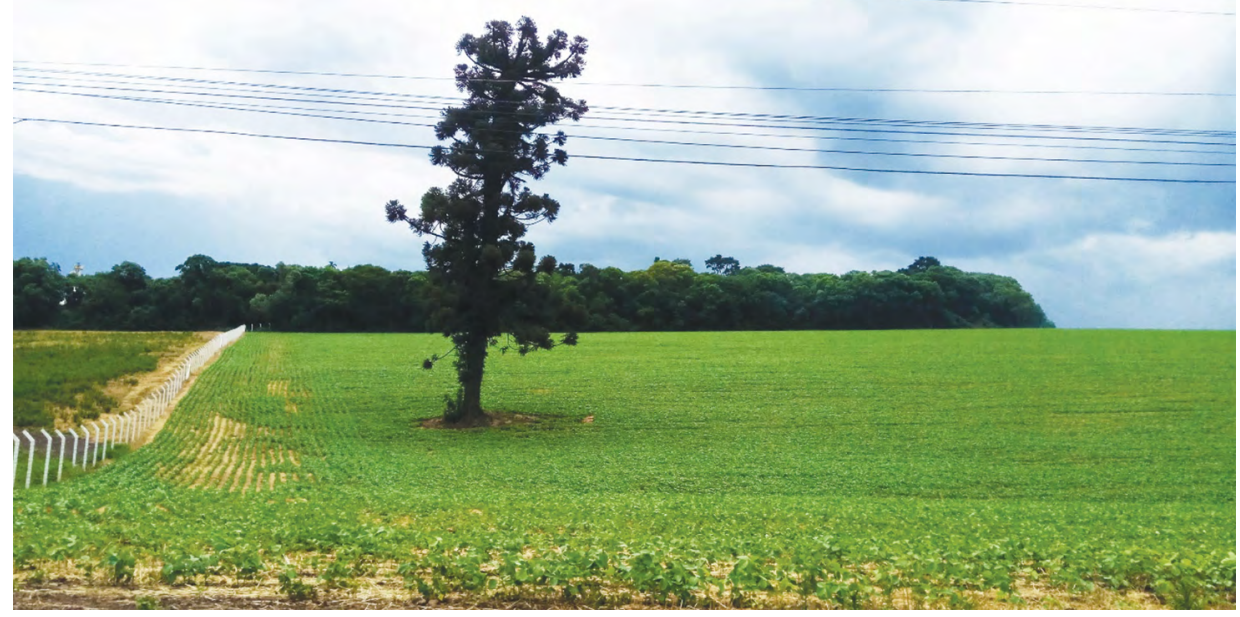

Figure 1: Materialities of the Soyacene: A lonely Araucaria or Paraná Pine tree (Araucaria angustifolia), a dominant arboreal species in the mixed ombrophilous forests characterising southern Brazil amid soya bean farming fields. Rural area of Chapecó, Santa Catarina, Brazil, December 2018.

Source: Photograph by Vitoria Fank Spohr, from the authors' archives.

Over the last decades, this large territory, comprising different tropical and subtropical bioregions, has become the most productive hub for the development of large-scale soya farming. Such a geographical focus mainly lies in the pioneering role of countries such as Brazil, Argentina and Paraguay in the acclimatisation of soya bean at different historical junctures and the introduction of varietiesfrom genetically modified to transgenic ones. As this article demonstrates, in Latin America, genetic variations and botanical selection went hand in hand with socioeconomic, political and ecological transformations. In addition, this essay indicates that the tropical bonanza of soya was also a key factor for converting soya beans into a global commodity that impacted the ecological balances of the biosphere. Within a few decades, soya bean monocultures have generated socio-environmental shifts in the territories that embraced its cultivation. As a result, in drawing an empirical outline of the development of large-scale soya bean farming in the Southern Cone, this article contributes both to global environmental history and to the growing field of Latin America's environmental history. In particular, it establishes a conversation with research efforts on the history of the plantation system in the continent and its 
socioecological transformative impact. ${ }^{10}$ Just as significantly, it contributes to recent studies on the role of transnational connections in the development of agricultural practices in Latin America. ${ }^{11}$

This article focuses on the tropical bonanza of soya in two defining moments. First, the process of soya bean cultivation and adaptation in subtropical regions of Latin America before the 1970s, looking at the role of national and foreign institutions and scientists interested in the expansion of this vegetal protein. Second, the implementation of soya farming at the Southern Cone's tropical latitudes and its socioecological impacts on several bioregions between the late 1960s and today. While the acclimatisation of soya beans was attempted several times in the course of the twentieth century, significant results only appeared in the late 1960s through the collaboration between Brazilian agencies and foreign technoscientific research institutes. As the soya bean began to conquer the Southern Cone, it increasingly figured in the political agendas of several countries and contributed to the creation of large agribusinesses. Overall, genetic manipulation, the yield of transgenic crops, and the conjunction of political and scientific interests led to the improvement of soya varieties, beginning the tropical bonanza of soya bean farming in the region. As soya crops thrived at new latitudes, they dramatically accelerated economic and socioecological trends, leading to the construction of the Soyacene. However, before

10 See for example Nicolo Gligo, Agricultura y Medio Ambiente en América Latina, San José (Mexico: Editorial Universitaria Centroamericana / Sociedad Interamericana de Planificación, 1986); María del Rosario Prieto, Estudios sobre historia y ambiente en América: Norteamérica, Sudamérica y el Pacífico (México: Instituto Panamericano de Geografía e Historia y El Colegio de México, 2002); Reinaldo Funes Monzote, From Rainforest to Cane Field in Cuba: An Environmental History since 1492 (Chapel Hill, NC: University of North Carolina Press, 2008), doi.org/10.5149/9780807888865_funes_monzote; Jó Klanovicz, 'Apple orchards in southern Brazil: An environmental history', in Comparing Apples, Oranges, and Cotton: Environmental Histories of the Global Plantation, ed. Frank Uekötter (Chicago: University of Chicago Press, 2014), 221-38; Shawn Van Ausdal and Robert Wilcox, 'Hoofprints: Cattle ranching and landscape transformation', in A Living Past: Environmental Histories of Modern Latin America, ed. John Siluri, Claudia Leal and José Augusto Pádua (New York: Berghahn Books, 2018), 183-204, doi.org/10.2307/j.ctvw04gzn.14; María Cecilia Gallero and Marina Miraglia, 'Transformaciones ambientales de la Selva Paranaense (relicto de la Mata Atlántica) en la triple frontera de Brasil-Argentina-Paraguay entre 1810 y 2020', Historia Ambiental Latinoamericana y Caribeña (HALAC) 11, no. 1 (2021): 222-52, doi.org/ 10.32991/2237-2717.2021v11i1.p222-252.

11 See for example Adrian Gustavo Zarrilli, 'Capitalism, ecology and agrarian expansion in the Pampean Region, 1890-1950', Environment and History 6, no. 4 (2001): 561-83, doi.org/10.2307/3985255; Stuart McCook, States of Nature: Science, Agriculture, and Environment in the Spanish Caribbean, 1760-1940 (Austin, TX: University of Texas Press, 2002); Shawn William Miller, An Environmental History of Latin America (New York: Cambridge University Press, 2007); Christiane Berth, 'Between "wild tropics" and "civilization": Guatemalan coffee plantations as seen by German immigrants', in Comparing Apples, Oranges, and Cotton: Environmental Histories of the Global Plantation, ed. Frank Uekötter (Chicago: University of Chicago Press, 2014), 113-38. Claiton Marcio Da Silva, De agricultor a farmer. Nelson Rockefeller e a modernização da agricultura no Brasil (Curitiba, Guarapuava: UFPR/ Unicentro, 2015); Claudio de Majo and Eduardo Relly, 'American vines, European potatoes: An evolutionary history of migrations in southern Brazil', International Review of Environmental History 6, no. 1 (2020): 5-29, doi. org/10.22459/IREH.06.01.2020.01; Claiton Marcio da Silva and Claudio de Majo, 'The making of a pastureland biome: American scientists, miracle grasses and the transformation of the Brazilian Cerrado', Environment and History Fast Track, doi.org/10.3197/096734020X15900760737338. 
diving into the core theme of this article, a brief historical overview of the origins of soya bean farming and its first journeys from the Far East to other parts of the world is due.

\section{From Eastern to Western soya beans}

Although the domestication of soya is still a contested topic, about 5,000 years ago, soya beans and soya foods were already produced and consumed in the northeastern Chinese region of Manchuria. Local farmers considered soya beans one of the five sacred cultivated crops together with rice, wheat, barley and millet. ${ }^{12}$ Its nutritional and functional characteristics allowed farmers not to leave their land fallow by including this nitrogen-fixing crop in their rotation regime. ${ }^{13}$ Farmers cultivated soya along the Liao River, utilising it to make fermented or otherwise processed foods. Also, oil processing residues produced soya bean cakes, whose nitrogen-fixing properties made them a popular fertiliser for nutrient-demanding crops such as cotton, rice and sugar. ${ }^{14}$

Before its official inception on global markets, the soya bean was introduced to Europe in the early 1700s, reaching botanic gardens in the Netherlands and France, and finally the royal garden at Kew by 1790 . The first official agricultural production was recorded in Dubrovnik (c.1800) and later in Romania, Bohemia and Austria. ${ }^{15}$ Concurrently, in 1766 a former seaman of the East India Company, Samuel Bowen, brought some soya varieties from the Chinese province of Canton (today Guangzhou) to the colonial Northern American region of Savannah, Georgia. ${ }^{16}$ By the mid-nineteenth century, soya farming experiences increased in the Western

\footnotetext{
12 Examples include different paintings, poems and botanic treaties such as Hsi Han's discourse on tropical botany, entitled Nan Fang Tshao Mu Chang. See Joseph Needham, Lu Gwei-Djen and Huang Hsing-Tsung, Science and Civilisation in China, vol. 6: Biology and Biological Technology. Part I: Botany (Cambridge: Cambridge University Press, 1986), 521.

13 Li-Juan Qiu and Ru-Zhen Chang, 'The origin and history of soybean', in The Soybean: Botany, Production and uses, ed. Guriqbal Singh (Wallingford: CABI, 2010), 1-23. Also see Diego da Silva Cunha et al., 'Soja para consumo humano: breve abordagem', Agrarian Academy 2, no. 3 (2015): 101-14, doi.org/10.18677/Agrarian_ Academy_010.

14 If placed underground, soya bean cakes are naturally fermented by soil microbes and employed today as a natural fertiliser in organic farming (see Hong-Bae Yun et al., 'The nitrogen, phosphate and potassium contents in organic fertilizers', Korean Journal of Soil Science and Fertilizer 44, no. 3 (2011): 498-501, doi.org/10.7745/ KJSSF.2011.44.3.498. On their historical role, see Ines Prodöhl, 'Versatile and cheap: A global history of soy in the first half of the twentieth century', Journal of Global History 8, no. 3 (2013): 461-82, doi.org/10.1017/ S1740022813000375.

15 Vuk Dordevic, 'Carte blanche: Soybean, the legume queen', Legume Perspectives 1 (2013): 4.

16 Theodore Hymowitz and J. R. Harlan, 'The introduction of soybean to North America by Samuel Bowen in 1765', Economic Botany 37, no. 4 (1983): 373, doi.org/10.1007/BF02904196.
} 
world, particularly in Prussia, the Netherlands and the south of the United States. The crop served mainly as forage and raw material to produce soya foods such as soya sauce and vermicelli. ${ }^{17}$

Despite its success in the Western world, the definitive consecration of soya as a global crop came once again from China, more specifically from the port of Yingkou, which became officially open to international trade as a result of the Second Opium War (1856-60). During the last decades of the nineteenth century, imperial tensions between Russia and Japan, combined with the Qing dynasty's efforts to extend its dominions over the country's north-east, stimulated rural development and enhanced transportation networks. As Ines Prodöhl argues, this transformation inaugurated a 'global history of soya beans and soy-related products. ${ }^{18}$ The globalisation of the soya bean was equivalent to its definitive 'Westernisation', as it became part and parcel of the transnational commercial entanglements propelled by the industrial revolution. Given the crop's capacity to acclimatise to different environments, and its industrial potential and versatility, soya bean varieties successfully navigated the nineteenth century. They became the object of agricultural experiments that would eventually lead to the 'age of soy' during the early twentieth century. ${ }^{19}$ In 1922 German botanist Hermann Bollmann (1880-1934) accidentally separated lecithin from soya oil, propelling the large-scale production of soy-derived oils. ${ }^{20}$ Bollmann's successful experiment was only one of the many improvements in industrial processing during the interwar period. In the United States, several firms began to promote territorial research after the creation of the American Soybean Association in 1920. Such an initiative epitomised the growing industrial interests of farming and producing derivates such as flour, sauce and bean curd or tofu. ${ }^{21}$ In the following years, experiments assessing the nutritional value of soya multiplied, propelled by George Washington Carver's influential experiments at the Tuskegee Institute (Alabama), with Lafayette Mendel and Thomas Osborne. By the early 1930s, the Western world manifested a growing interest in the research and improvement of breeding varieties, especially the United States, though its production rates were still lower than China, Japan and Korea. ${ }^{22}$ The arrival of a wide array of seeds from

17 Vermicelli is a traditional type of round pasta similar to spaghetti. While in the Western world pasta is normally made of wheat, the term can also be used to describe various type of thin noodles originally from Asia. For the use of soya foods in the United States, see Hymowitz and Harlan, 'The introduction of soybean to North America', 373, and Maria Cristina Dias Paes, Princípios básicos de nutrição e uso da soja na alimentaçâo humana (Londrina: EMBRAPA-CNPSo, 1994).

18 Prodöhl, 'Versatile and cheap', 467.

19 For an overview of the history of soya, see Christine Du Bois, The Story of Soy (London: Reaktion Books, 2018). Also see Christine Du Bois, Sidney Mintz and Chee-Beng Tan, eds, The World of Soy (Urbana, IL: University of Illinois Press, 2008).

20 Prodöhl, 'Versatile and cheap', 467.

21 Cunha et al., 'Soja para consumo humano', 102.

22 J. B. Ferraz de Meneses Júnior, 'Soja: origem, composição química, valor nutritivo e aplicaçôes diversas', Revista do Instituto Adolfo Lutz 31 (1961): 33-56. 
different regions of Asia propelled the capillary expansion of farming in the United States. By 1939, William J. Morse and Jackson L. Cartter described 108 cultivars in the United States, all introduced from Asia or natural crosses of introduced crops. ${ }^{23}$

Soya's botanic success in Northern America mainly lay in its physiological capacity to adapt to temperate or subtropical climates, predominant in latitudes approaching or above $30^{\circ} \mathrm{C} .{ }^{24}$ The combination of cutting-edge agricultural research, extensive cultivable lands and a growing industrial economy turned the United States into the leading soya producer in the Western world between the late eighteenth century and the Second World War. As the global demand for soya continued to increase in the following decades, due to the combination of global demographic growth, higher incomes and significant crop shortfalls in several producing countries, its uses multiplied: about 20 per cent of the soya produced since the 1950 s was crushed for oil, and from the 1960s meals became essential supplements for animal farming, especially for the production of pork, poultry and eggs. ${ }^{25}$ The growing expansion of soya also allowed farming activities to gain ground in the southern hemisphere's subtropical latitudes, a process complemented by several crucial steps in agricultural selection.

\section{The rise of soya in Latin America's subtropics (1892-1960)}

Although the United States quickly became the world's leading soya producer, several selected varieties also reached subtropical Latin America during the late nineteenth and early twentieth centuries. ${ }^{26}$ These were, in chronological order, Brazil (1882), Argentina (1908), Uruguay (1911), Paraguay (1921) and finally Bolivia (1928). ${ }^{27}$ It is crucial to observe that this was not a unidirectional process, where all experiences

23 As revealed by recent genomic analyses, 95 per cent of the genetic basis of current soybean cultivars in the United States derives from 37 early introduced varieties. See Edwin J. Anderson et al., 'Soybean [Glycine max (L.) Merr.] breeding: History, improvement, production and future opportunities', in Advances in Plant Breeding Strategies: Legumes, vol. 7, ed. Jameel M. Al-Khayri, Mohan Jain and Dennis V. Johnson (Berlin: Springer, 2019), 431-516.

24 Anderson et al., 'Soybean [Glycine max (L.) Merr.]', 438.

25 On the rise in soybean demand, see Bryan L. McDonald, Food Power: The Rise and Fall of the Postwar American Food System (New York: Oxford University Press, 2017), doi.org/10.1093/acprof:oso/9780190600686.001.0001, and FAO, Soybean Prices, Economic Growth and Poverty in Argentina and Brazil (Rome: Food and Agriculture Organization of the United Nations, 2017): 3, www.fao.org/3/I8316EN/i8316en.pdf, accessed 28 July 2021. On utilization increase, see Lester Brown, Full Planet, Empty Plates: The New Geopolitics of Food Scarcity (New York: Norton, 2012): 94-5.

26 The temperate climate area in Brazil is localised between the $23^{\circ} 30^{\prime}$ and $33^{\circ} 45^{\prime}$ southern parallels, involving the southernmost states of Rio Grande do Sul and Santa Catarina, and part of Paraná. Average temperatures during the hottest months can exceed $22^{\circ} \mathrm{C}$, while coldest temperatures oscillate between $-3^{\circ} \mathrm{C}$ and $18^{\circ} \mathrm{C}$. See Brazilian Institute of Geography and Statistics (IBGE), Mapa de clima do Brasil (Rio de Janeiro: IBGE, 2002), atlasescolar. ibge.gov.br/images/atlas/mapas_brasil/brasil_clima.pdf, accessed 28 July 2021.

27 William Shurtleff and Akiko Aoyagi, History of Soybeans and Soyfoods in South America (1882-2009) (Lafayette, CA: Soyinfo Center, 2009), www.soyinfocenter.com/pdf/132/LaSo.pdf, accessed 28 July 2021. 
of soya cultivation followed the same genomic thread. On the contrary, distinct varieties reached several countries at different times through botanic gardens, schools and laboratories, or members of local elites explicitly concerned for agricultural and economic development. However, in not all instances were scientists and botanists responsible for advancing soya yields and productivity. As an example, the first soya cultivation experience in Brazil related by agronomist Gustavo D'Utra from the Imperial Agrarian School of Bahia (Imperial Escola Agricola da Babia), described cultivation experiences carried out by a farmer from the municipality of Cruz das Almas, Bahia, in $1882 .{ }^{28}$ At the time commercial soya production was restricted to North America and eastern Asia at latitudes approaching $40^{\circ} \mathrm{N}$, characterised by a temperate climate, in stark contrast to the tropical climate and lower margins $\left(12^{\circ} \mathrm{S}\right)$ of the Brazilian state of Bahia. ${ }^{29}$ In 1891-92, the Austrian botanist Franz W. Daffert carried out an experiment in the Agronomic Institute of Campinas (Instituto Agronomico de Campinas, IAC), located in the rural area of the state of São Paulo-more than $1,800 \mathrm{~km}$ to the south of Cruz das Almas, at the crossroads with the subtropical latitudes of the Tropic of Capricorn. By 1901, Gustavo D'Utra had become the IAC's director and began new experiments, distributing new seeds among local farmers- $28 \mathrm{~kg}$ of yellow seeds and $18 \mathrm{~kg}$ of black ones. ${ }^{30}$

Several years later, with the intensification of Japanese migration to Brazil after 1908, availability increased. Japanese immigrants probably cultivated varieties originally from their homeland, mainly in domestic gardens located in the rural areas of São Paulo, producing small yields primarily destined to the production of tofu, miso and shoyu. ${ }^{31}$ Westernised soya varieties selected in the United States also reached Brazil in the same period. For example, by 1921, new experiments were carried out by the agronomist Henrique Löbbe in São Simão (São Paulo). Although maize constituted the primary culture, in 1926, Löbbe introduced selected seeds from Manchuria and the United States that were very successful in the region. ${ }^{32}$ During the 1930s, Löbbe also visited a soya farm in Arlington, Virginia, where he received 51 new varieties. Overall, Löbbe’s experience in São Simão resulted in a detailed guide to soya farming, including the preparation of soil, sowing and acclimatisation processes, dealing with diseases, the use of fodder, the processing of seeds into oil cakes, and modes of human consumption. ${ }^{33}$

28 Geraldo Hase Ceval and Fernando Bueno, O Brasil da Soja Abrindo Fronteiras, semeando cidades (Gaspar: Ceval Alimentos, 2000): 9.

29 Embrapa, Tecnologias de Produção de Soja-Regiäo Central do Brasil-2004 (Londrinha: Embrapa Soja, 2003): 9. See also Amélio Dall'Agnol, A Embrapa Soja no contexto do desenvolvimento da soja no Brasil: histórico e contribuiçôes (Londrinha: Embrapa Soja, 2016): 20.

30 Claudine Dinali Santos Seixas et al., Tecnologias de Produção de Soja (Londrinha: Embrapa Soja, 2020). Also see Ceval and Bueno, O Brasil da Soja, 9.

31 Ceval and Bueno, O Brasil da Soja, 9.

32 João Rui Jardim Freire and Francisco de Jesus Vernetti, 'A pesquisa com soja, a seleção de rizóbio e a produção de inoculantes no Brasil', Pesquisa Agropecuária Gaúcha 5, no.1 (1999): 117-26.

33 Henrique Löbbe, Cultura da Soja no Brasil (Rio de Janeiro: Serviço de Informação Agrícola, 1939). 
As previously mentioned, in contrast to the temperate latitudes where soya was first domesticated, the state of São Paulo is located between the Tropic of Capricorn and the equator, which suggests a significant change from the original environment of cultivation. Simultaneously, towards the beginning of the twentieth century, soya reached subtropical Brazilian territories that have temperatures resembling the climate patterns of the southern United States where they had previously thrived. These were particularly successful in the southernmost state of Rio Grande do Sul. Historical records demonstrate that, by 1901, some agrarian experiments related to farming were carried out by the Liceu Rio-Grandense de Agronomia in Pelotas, Dom Pedrito, Pinheiro Machado and Venâncio Aires (over 3,000 km from Cruz das Almas). The French agronomist Guilherme Missen documented Dom Pedrito's experience, allegedly the first soya harvest in Latin America, a total yield of 2,800 $\mathrm{kg}$ per hectare, mainly destined for cattle feed. ${ }^{34}$ The head of the operation, the Brazilian engineer and agronomist Alberto Wellhauser, related that soya crops reached the optimal maturation height of $60 \mathrm{~cm}$, despite a drought. ${ }^{35}$

By 1914, the US agronomist E. C. Craig, professor at the Technical University of Rio Grande do Sul, introduced other American varieties. ${ }^{36}$ About six years later, in 1920, European immigrants inhabiting the municipality of Santa Rosa began to test soya as a complement to coffee plantations, mainly for domestic consumption. ${ }^{37}$ In 1923, the US Lutheran pastor Albert Lehenbauer introduced a more systematic model of production for swine feeds through the combination of pumpkin, manioc, maize and other organic waste. ${ }^{38}$ However, the most crucial historical caesura in the Manchurian-Japanese-American soya connection was the internal propagation of soya varieties carried out by Polish immigrants during the early 1930s. ${ }^{39}$ First, the Polish agronomist and diplomat T. Makomaski allegedly convinced his fellow immigrants to increase soya farming activities, a choice that dramatically improved crop yields. In the same years, a Polish immigrant and agronomist, Cesłau Bieżanko, experimented with novel soya breeding techniques in Santa Rosa (Rio Grande do Sul). Bieżanko is today celebrated as one of the leading soya pioneers, whose experiments contributed to turning Santa Rosa into the 'national capital of soy'. ${ }^{40}$

\footnotetext{
34 Ceval and Bueno, O Brasil da Soja, 9.

35 While the optimal height for soya bean plants at maturation is generally $60 \mathrm{~cm}$, modern genetically engineered Brazilian plants can reach up to $150 \mathrm{~cm}$. See José Luis da Silva Nunes, 'Características da soja', Agrolink, www. agrolink.com.br/culturas/soja/informacoes/caracteristicas_361509.html, accessed 28 July 2021. For the Welhauser accounts, see Adilson Nunes de Oliveira and Antônio Ribas, Dom Pedrito: Pioneira no cultivo de soja na América Latina (Porto Alegre: Evangraf, 2010): 9.

36 Rhuan Targino Zaleski Trindade, 'A soja e os colonos poloneses no sul do Brasil: o caso de Ceslau Biezanko e outros personagens (1930-1934)', História Unisinos 22, no. 2 (2018): 254-63, doi.org/10.4013/htu.2018.222.09.

37 Ceval and Bueno, O Brasil da Soja, 9.

38 Zaleski Trindade, 'A soja e os colonos poloneses', 257. See also Ceval and Bueno, O Brasil da Soja, 9.

39 Freire and Vernetti, 'A pesquisa com soja', 117-18.

40 Zaleski Trindade, 'A soja e os colonos poloneses', 260.
} 
Through the combination of these experiences, by the late 1930s, farming in Brazil intensified, initiating the first processes of large-scale dissemination. In particular, the state of Rio Grande do Sul became the epicentre of what later became the 'United Republic of Soy'. ${ }^{41}$ As is demonstrated by the Polish case, the expansion of cultivation primarily involved groups of European immigrants, who began to massively occupy the southern territories of Brazil in the late nineteenth and early twentieth centuries. Clearing the land and annihilating local indigenous people, they embodied the country's political agenda: filling the 'demographic gap' of the southern frontier through the advent of white colonisers willingly to embrace intensive farming and private land ownership. ${ }^{42}$ The most powerful impulse for success was soya's substitution for wheat as the primary agricultural produce. ${ }^{43}$ Since the late 1930s, farmers from Rio Grande do Sul had exported their varieties to Germany. After 1942, following trade restrictions against the Axis powers, they attempted to redeem soya overproduction with the manufacturing of vegetal oils. Later, towards the 1950s, the IAC sent new varieties to southern Brazil through José Gomes da Silva and Shiro Miyasaka. ${ }^{44}$ With the help of Chinese agronomists, local farmers began to acquire significant breeding and farming know-how. ${ }^{45}$

A similar process happened in Argentina, a country that also received a large inflow of European immigrants, who were encouraged to practise cultivation. ${ }^{46}$ The first soya breeding experiments were carried out by the Experimental Station (Estación Experimental), a research organisation annexed to the National School of Agriculture and Livestock of Córdoba (Escuela Nacional de Agricultura y Ganadería de Córdoba) created in 1909-12. ${ }^{47}$ These were linked to the experiences of southern Brazilian farmers, given the common subtropical climatic patterns and the cooperative

41 By 2003, the corporation Syngenta advertised its services linked to soybean production in the Argentinean newspapers Clarin and La Nación, renaming the soy-producing territories of the Latin American Southern Cone (parts of Brazil, Argentina, Uruguay, Paraguay and Bolivia) with the term 'United Republic of Soy'. See GRAIN, 'La República Unida de la Soja recargada' (12 June 2013), www.grain.org/es/article/4739-la-republica-unida-de-lasoja-recargada, accessed 28 July 2021.

42 See Beatriz Maria Lazzari, Imigração e ideologia. Reação do Parlamento brasileiro à política de colonização e imigração (Caxias do Sul: UCS, 1980).

43 During the colonial period (1500-1822), the occupation of the current Brazilian territory was mainly concentrated on the coast, with few expeditions in the inner territory. Following Brazilian independence, these lands, still inhabited for the most part by indigenous people, were considered as terrae nullius that needed to be conquered in order to fill the 'demographic vacuum'. See Paulo Zarth, José Carlos Radin and Delmir Valentini, eds, História da Fronteira Sul (Chapecó and Porto Alegre: UFFS / Letra e Vida, 2015); Henrique Manoel da Silva, 'Os brasileiros em território paraguaio: atuação nas fronteiras geográficas próximas', in Colonizaçâo, conflitos e convivências nas fronteiras do Brasil, da Argentina e do Paraguai, ed. Vladimir Muraro and Delmir Valentini (Chapecó, Ed. UFFS, 2015), 23-39.

44 Freire and Vernetti, 'A pesquisa com soja', 118.

45 See Geraldo Hasse, A rainha do agronegócio—a história da soja no Brasil (Ribeirão Preto-SP: Editora Coruja, 2011): 74 .

46 Derli Dossa, Soja: alguns aspectos de sua participação no mundo, no Brasil e na produção primária e agroindustrial do Paraná (Brasilia: Embrapa, 1986).

47 Diego Martínez Alvarez, 'Historia de la soja en la Argentina: Introducción y adopción del cultivo', in El cultivo de soja en Argentina, ed. Hector E. J. Baigorri and Luis R. Salado Navarro (Buenos Aires: Agroeditorial, 2012): 13. 
relations between immigrants with European ancestry. Towards the early 1940s, through the intersection of research stations and private companies, new northern American varieties were introduced in Argentina, laying the foundation for expanding intensive farming in the following decades. ${ }^{48}$ Concurrently with the Argentinean expansion, by 1946, the IAC introduced 14 new varieties in Paraguay, another country crossed by the Tropic of Capricorn. ${ }^{49}$ In the same years, soya cultivation intensified in Uruguay, mainly in Paysandu, Rio Negro, Soriano and Colonia. ${ }^{50}$

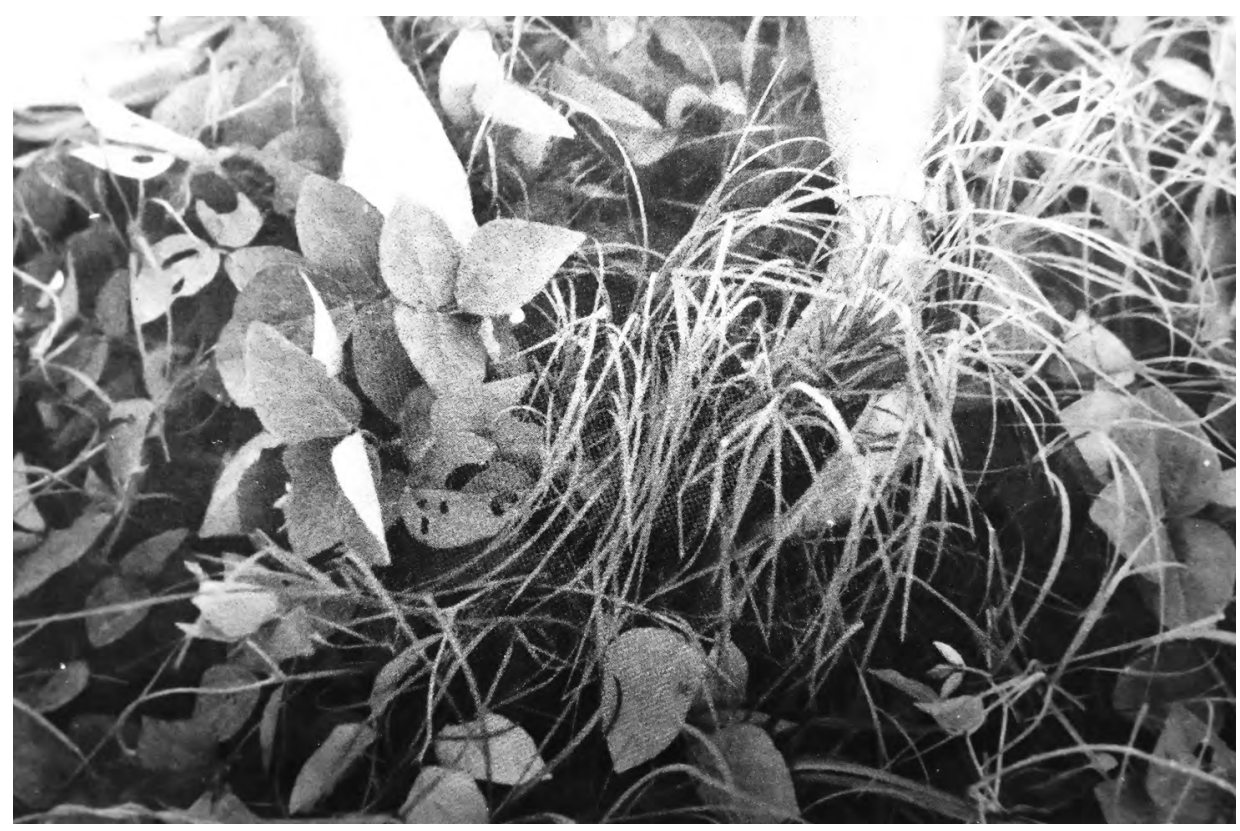

Figure 2: Perennial growing in combination with Suwannee bermuda grass in the 1950s. American International Association for Economic and Social Development and its IRI Research Institute division. Progress Report. New York, 3 September 1958.

Source: Courtesy of the Rockefeller Archive Center.

48 Pedro Jesus Rocha and Victor Manuel Villalobos Arambula, Comparative Study of Genetically Modified and Conventional Soybean Cultivation in Argentina, Brazil, Paraguay, and Uruguay (San José, CR: Inter-American Institute for Cooperation on Agriculture (IICA), 2012).

49 Derli Dossa, Soja.

50 Rocha and Villalobos Arambula, Comparative Study. 
Thus, although the first agricultural experiments with soya involved tropical regions such as Bahia until the 1970 s, the crop mainly prospered in subtropical areas. ${ }^{51}$ After the Second World War, southern Brazil and northern Argentina joined the world's leading soya producers, thanks to national investments in farming technologies and the creation of agricultural cooperatives. ${ }^{52}$ An IAC partnership with private farmers during the 1950s created a cutting-edge research program that selected new varieties for the local territory, such as Mogiana, Aliança and Yelnando. The institute also bred varieties for the tropical savannahs of the Brazilian Cerrado, such as Cultivares Araçatuba and Pelicano. ${ }^{53}$ In the same period, the IAC also carried out experiments in farming in collaboration with Nelson Rockefeller's IRI Research Institute, with a particular focus on the perennial soya bean (Glycine soja or Neonotonia wightii Verde). This variety, originally from Southeast Asia, was introduced in the state of São Paulo in 1953. From 1956 it was distributed among local farmers as a fodder and pasture crop. However, despite its initially good results, germination issues in lower topsoil and low productivity led to its progressive demise. ${ }^{54}$

These initial attempts were just the beginning of a long series. With the progressive erosion of southern Brazilian soils, the exhaustion of arable lands and demographic increase, immigrants from Rio Grande do Sul also occupied lands of other states such as Mato Grosso, Mato Grosso do Sul and Goiás. This internal migration pushed Brazilian scientists to select new varieties adapted to the acidic soils of the Cerrado, especially after the 1973 oil crisis and the consequent increase in soya prices. ${ }^{55}$ These were the first steps leading to the final consecration of soya as a global crop, stimulating the agricultural revolutions in entire bioregions previously considered unsuitable for intensive monoculture.

\footnotetext{
51 Genetic material from the United States was always better adapted to the ecological conditions of southern Brazil and presented better agronomic characteristics and resistance. While hybridisation and selection processes began in Brazil, local farmers mainly used soya crops introduced from the United States, such as Hill, Hood, Majos, Bragg, Davis, Jew 45, Hampton, Hardee or Bienville. By 1967, the IAC launched the crops Santa Rosa and Industrial, which became widespread among farmers from Rio Grande do Sul. For further information see Freire and Vernetti, 'A pesquisa com soja', 120.

52 Rocha and Villalobos Arambula, Comparative Study.

53 Orlando Melo de Castro and Antonio Carlos Moreira, ed., Ciência da Terra: o Instituto Agronômico e a pesquisa em beneficio da qualidade de vida (Campinas: IAC, 2008): 45.

54 See Luiz Lovadini, 'Método de plantio para soja perene (Glycine wightii Verdc.)', Bragantia 30, no. 1 (1971): xvii-xix, doi.org/10.1590/S0006-87051971000100012.

55 Claiton Marcio da Silva, 'Between Fenix and Ceres. The Great Acceleration and the agricultural frontier in the Brazilian Cerrado', Varia Historia 34, no. 65 (2018): 409-44, doi.org/10.1590/0104-87752018000200006.
} 


\section{Tropical farming: Genetic modification and transgenic crops (1970-2010)}

The tropical bonanza of soya officially began in the 1970s and played a central role in the crop's transformation into a global commodity. In practical terms, this process consisted of the progressive adaptation of soya to low latitudes, occupying arable lands originally destined for pasture, traditional cultivation, small monocultures and conservation areas. Consequently, a vast tropical region sitting between the Tropic of Capricorn and the equator began to produce soya on a large scale. It encompassed the Gran Chaco plains of Argentina, Paraguay, Bolivia and Brazil, Bolivia's Chiquitano forest and two large Brazilian bioregions such as the Cerrado and the Amazon. ${ }^{56}$ In several regions, the significant growth of farming also propelled the expansion of the agricultural frontier and large-scale urbanisation. ${ }^{57}$ This historical transition was part of an ambitious agricultural modernisation agenda carried out all over the Latin American tropics during the 1970 s to convert infertile soils to agriculture. ${ }^{58}$ Such a project found historical momentum in the already-mentioned growth of soya on international markets since the 1950s. This process would eventually lead the United States to place an embargo on the crop and other oilseed products, leading to a historic peak in prices in June 1973 (US\$393 per metric ton [MT]). However, as the United States reduced their exports, countries in need such as Japan began to look for alternative markets, stimulating Brazil and other Latin American countries to enhance production indexes. ${ }^{59}$

As a result, Latin American nations seized the moment, devising strategies to expand production. These mainly consisted of adapting soya crops to local acidic soils, local diseases and extended daylight periods. ${ }^{60}$ However, since soya varieties from the United States could not adapt to local climate patterns, scientists actively worked to improve soya's productive genetic potential. ${ }^{61}$ Given the promising economic outcomes of the Brazilian 'genetic turn', public and private research institutes researching soya crops began to feature prominently in the technocratic agendas promoted by several Latin American countries between the mid-1960s and the

\footnotetext{
56 Silvio Crestana and Ivan Sergio Freire de Sousa, 'Agricultura tropical no Brasil', in Agricultura Tropical. Quatro décadas de inovaçôes tecnológicas, institucionais e políticas, vol. I: Produção e produtividade agrícola, ed. Ana Christina Sagebin Albuquerque Aliomar Gabriel da Silva (Brasília: Embrapa, 2008): 45.

57 Amélio Dall'Agnol, 'A soja que não se curva' (11 July 2017), blogs.canalrural.com.br/embrapasoja/2017/07/11/ soja-que-nao-se-curva, accessed 28 July 2021.

58 Silva, 'Between Fenix and Ceres',

59 FAO, Soybean prices, 3.

60 This was caused both by their sensitivity to photoperiods and to their short size, which did not allow systematic mechanised harvesting. See Freire and Vernetti, 'A pesquisa com soja', 120-1.

61 Romeu Afonso de Souza Kiihl and Éberson Sanches Calvo, 'A Soja no Brasil, mais de 100 anos de história, quatro décadas de sucesso', in Agricultura Tropical. Quatro décadas de inovaçóes tecnológicas, institucionais e políticas, vol. I: Produção e produtividade agrícola, ed. Ana Christina Sagebin Albuquerque Aliomar Gabriel da Silva (Brasília: Embrapa, 2008): 207.
} 
mid-1980s. For example, the Brazilian military regime promoted a modernising agrarian agenda geared to improving the production of agricultural commodities for the international market. Its main highlights were the increase of rural credit extension services for all the country's regions, which enhanced the availability of agricultural machinery, fertilisers and seeds. ${ }^{62}$ In addition, military regimes strengthened several programs of international cooperation with American foundations that had been initiated during the 1950 s. ${ }^{63}$ For example, in 1973, a pool of Brazilian entrepreneurs and intellectuals created the Brazilian Agricultural Research Corporation (Empresa Nacional Brasileira de Pesquisa Agropecuaria, EMBRAPA) that incentivised the formation of a technical framework of scientists trained in North American institutions, with a research unit specialised on soya. ${ }^{64}$ In this context, cooperation with Japan played an essential role in consolidating rural development programs in the Brazilian Cerrado.

As a result, in 1964, Francisco Terasawa created the soya crop Cristalina, one of the most cultivated crops in the Cerrado until the 1990s. ${ }^{65}$ Later on, in the mid-1970s, Brazilian scientists from both public and private corporations-respectively, the already-mentioned EMBRAPA and the FT Sementes (created by Terasawa himself in 1972)—were able to successfully introduce genes adapted for the 'long juvenile period' in the germplasm of Brazilian crops. This genetic modification allowed soya crops to adapt to tropical seasons, as they did not forcefully blossom before their juvenile period (or sub-growing season). Complementarily, scientists led successful experiments to select crops resistant to disease and concentrated on bacterial diseases such as citrus canker (Xanthomonas axonopodis pv. glycines Nakano), Diaporthe phaseolorum var. sojae, cyst nematode (Heterodera glycines Ichinohe), root-knot nematodes (Meloidogyne incognita [Kofoid \& White] Chitwood and Meloidogyne javanica [Treub] Chitwood). Crop selection allowed a 50 per cent increase in annual production rates. ${ }^{66}$ Subsequently, a 1979 joint Japanese-Brazilian agrarian development program known as PRODECER (Programa de Cooperação Nipo-Brasileiro para o Desenvolvimento Agricola dos Cerrados) helped sustain the

62 Silva, 'Between Fenix and Ceres', 411.

63 These included the Rockefeller Foundation, the American International Association, the International Basic Economy Co., the IRI Research Institute, the Ford Foundation and the US Agency for International Development. See Claiton Marcio da Silva, De agricultor à farmer: Nelson Rockefeller e a modernizaçāo da agricultura no Brasil (Curitiba and Guarapuava: UFPR/Unicentro, 2015).

64 See Embrapa, 'Soybean - history', www.embrapa.br/en/soja/historia, accessed 28 July 2021.

65 Francisco Terasawa, José Maurício Terasawa and Milene Terasawa, 'FT Sementes and the expansion of soybeans in Brazil', in Soybean Breeding, ed. Felipe Lopes da Silva et al. (Berlin: Springer, 2017), 17-27, doi.org/ 10.1007/978-3-319-57433-2_2.

66 De Souza Kiihl and Sanches Calvo, 'A Soja no Brasil', 207-8. 
systematic advancement of agriculture in tropical Brazil. ${ }^{67}$ Overall, the combination of these efforts led to the significant expansion of the tropical soya frontier in the Brazilian Cerrado. Between the beginning of the 1970 s and the end of the 1990s, Brazilian production increased from 5.6 to 27.5 MMT. The total farmed area also expanded almost 200 per cent (from 3.7 to 12 million hectares Mha), with a total yield increase from 1,460 to 2,294 metric tons per hectare (MT/ha). ${ }^{68}$ It was the beginning of large-scale agricultural mechanisation in the vast bioregion of the Cerrado, with soya as the main actor. In the same period, farming also had a significant boost in Argentina, where total production increased from 2.2 to 11.4 MMT between 1975 and 1999, with substantial growth in both the total planted area and productivity indexes_respectively, from 1.2 to $7.4 \mathrm{Mha}$ and from 1.461 to $2.261 \mathrm{MT} / \mathrm{ha}^{69}$ Overall, the experiences of Brazil and Argentina served as trailblazers for the further consolidation of monoculture during the following decades, a process fuelled by the rise of transgenic crops.

During the 1990s, countries such as Argentina and the United States allowed the cultivation of transgenic soya (GM-GR), a game-changing soya crop capable of tolerating a glyphosate-based pesticide known as Roundup Ready. The implanting of genes from Agrobacterium sp., a soil bacterium containing a specific enzyme able to inhibit the amino acid metabolism of plants, built pesticide resistance. ${ }^{70}$ By resisting intense glyphosate fumigation, transgenic soya eliminated competition from weeds and minimised the risk of parasites, which were annihilated by the pesticide, thus optimising production and productivity. Moreover, Roundup's weed elimination allowed the sowing of transgenic crops without harrowing the land, leading to 'no-till' farming. ${ }^{71}$ The American multinational Monsanto patented this game-changing biotechnology. After lobbying for the legalisation of genetically modified (GM) crops by the US Department of Agriculture in 1994, in 1996, the company cleverly opened a breach in the Argentinean market. Agricultural investment funds, megaagricultural firms, agribusiness contractors and a minority of medium-scale farmers facilitated this process, while small farmers went bankrupt. ${ }^{72}$ Overall, transgenic crops allowed a significant increase in national production rates: between 1980 and 2005, the area of Argentinean subtropical territories covered by soya increased

67 Although PRODECER was not the only program responsible for the agrarian changes affecting the region over the last 30 years, its contribution was certainly significant in the evolution and cultivation of soya, maize, coffee and cotton in the Brazilian Cerrado. See Clóvis Caribé Menezes dos Santos, 'Programa de Cooperação NipoBrasileira para o Desenvolvimento dos Cerrados_PRODECER: um espectro ronda os cerrados brasileiros', Estudos Sociedade e Agricultura 24, no. 2 (2016): 384-416.

68 FAO, Soybean Prices, 5.

69 Ibid.

70 See Antônio Inácio Andrioli, Soja orgânica versus soja transgênica: um estudo sobre tecnologia e agricultura familiar no noroeste do Estado do Rio Grande do Sul (Chapecó: UFFS, 2017): 167. Also see Rubens Nodari and Miguel Pedro Guerra, 'Plantas transgênicas e seus produtos: impactos, riscos e segurança alimentar (Biossegurança de plantas transgênicas)', Revista de Nutrição 16, no. 1 (2003):105-16, doi.org/10.1590/S1415-52732003000100011.

71 Pablo Lapegna, Soybeans and Power: Genetically Modified Crops, Environmental Politics, and Social Movements in Argentina (New York: Oxford University Press, 2016), 28, doi.org/10.1093/acprof:oso/9780190215132.001.0001.

72 Lapegna, Soybeans and Power, 32. 
from 2 to $17 \mathrm{Mha}$, it becoming the country's most cultivated and exported crop. ${ }^{73}$ It was the beginning of the process known as sojizacion (literally 'soy-isation'), which would lead to the conversion of several natural areas in Argentina, Brazil, Paraguay, Uruguay and Bolivia to monocultures aimed at the production of transgenic soya. ${ }^{74}$

After the commercialisation of GM-GR varieties in Argentina, transgenic varieties were smuggled into Paraguay and Brazil as a strategy to force the approval of Roundup pesticides. After pressure by farmers' associations and agribusiness lobbyists who had already de facto spread crops over thousands of hectares, transgenic soya was approved in 2004 and 2005, respectively. ${ }^{75}$ By 2011, combined production indexes of GM crops-mostly soya, maize and cotton-in Latin America totalled 40 per cent of total world production. Soya monoculture stretched over $66 \mathrm{Mha}^{76}$ According to an enthusiastic survey carried out by the Argentinean Ministry of Agriculture, Livestock and Fisheries and the Costa Rican Inter-American Institute for Cooperation on Agriculture (IICA) in 2012, the increase generated an economic return of $\$$ US5 billion to local farmers. ${ }^{77}$

The progressive introduction of transgenic soya in Latin America from the 1990s expanded the cultivation area to new agrarian frontiers in tropical territories previously dominated by other crops, pasturelands or conservation areas. These included parts of the Brazilian state of Bahia, where soya returned in a potentiated version more than a century after its initial introduction in 1882 . The development of new agricultural areas in Brazil also included north-eastern and northern regions with no previous farming experience, such as Maranhão, Piauí and Tocantins (north of Bahia). Together they formed the country's last agricultural frontier, a region commonly known as MATOPIBA. ${ }^{78}$ Moreover, with the development of transgenic crops such as the BRS Tracajá in 1999-2000, farming gained ground in the South of Pará, after advancing through other Amazonian states such as Mato Grosso and Rondônia. ${ }^{79}$

73 Carlos Reboratti, 'Un mar de soja: la nueva agricultura en Argentina y sus consequencias', Revista de geografía Norte Grande 45 (2010): 63-76, doi.org/10.4067/S0718-34022010000100005. See also Departamento de Desarrollo Sostenible de la Organización de los Estados Americanos, Evaluación regional del impacto en la sostenibilidad de la cadena productiva de la soja: Argentina_Paraguay_Uruguay (December 2009), 29.

74 See Pierre Delvenne, Federico Vasen and Ana Maria Vara, "The "soy-ization" of Argentina: The dynamics of the "globalized" privatization regime in a peripheral context', Technology in Society 35, no. 2 (2013): 153-62, doi.org/10.1016/j.techsoc.2013.01.005; Mabel Manzanal, 'Territorio, Poder y Sojización en el Cono Sur latinoamericano. El caso argentino', Mundo Agrario 18, no. 37 (2017): e048, doi.org/10.24215/15155994e048.

75 Rocha and Villalobos Arambula, Comparative Study.

76 Lapegna, Soybeans and Power, 5-6.

77 Rocha and Villalobos Arambula, Comparative Study.

78 See Sandro Dutra e Silva, Kárita de Jesus Boaventura, Eder Dasdoriano Porfírio Júnior, et al., 'A última fronteira agrícola do Brasil: o Matopiba e os desafios de proteção ambiental no Cerrado', Estudios Rurales 8, no. 15 (2018): 145-78.

79 Experiments with BRS Tracajá were also conducted in the municipalities of Maranhão, Piauí, Tocantins and Roraima. For further information see Jamil Chaar El-Husny et al., BRS Tracajá: cultivar de soja para a regiäo Sul do Pará, Comunicado Técnico 83 (Belém: Embrapa, 2003). 

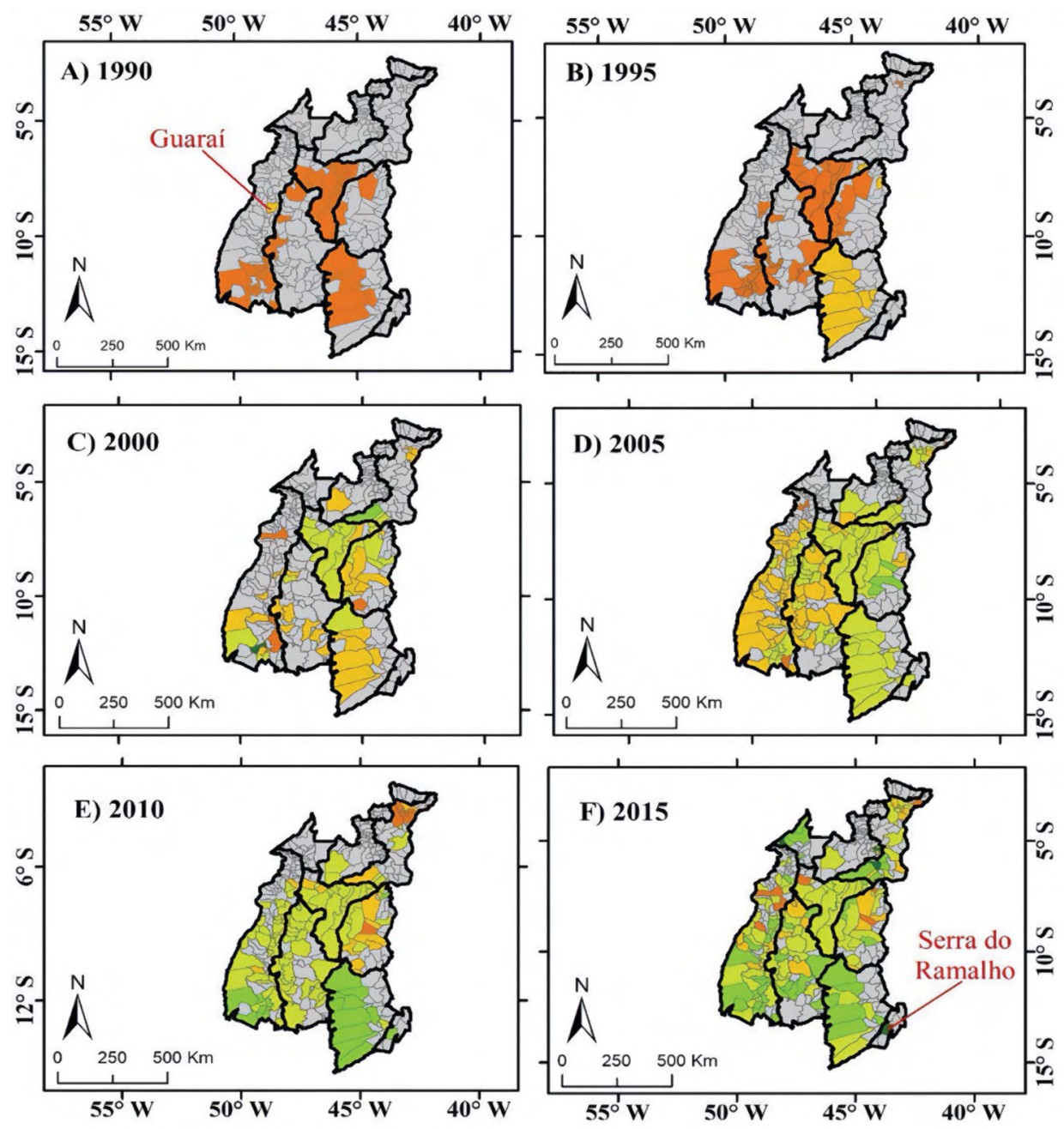

Produtividade (t/ha)

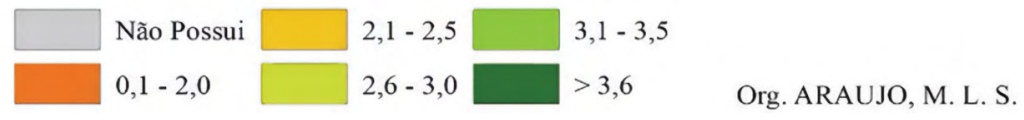

Map 1: Soya production and productivity (T/ha) growth in MATOPIBA between 1990 and 2015.

Source: Mayara Lucyanne de Araújo, 'Dinâmica espaço-temporal da cultura de soja na região do MATOPIBA, Brasil (1990-2015)' (Master's diss. in Applied Geoscience and Geodynamics, University of Brasília (Geoscience Institute), 2018), repositorio.unb.br/bitstream/10482/32871/1/2018_ MayaraLucyanneSantosdeAra\%c3\%bajo.pdf, accessed 27 July 2021. 
Between 1976 and 2019, production in Brazil, Argentina, Uruguay and Paraguay grew from 12 to $180 \mathrm{MMT}$ and 7 to $56.9 \mathrm{Mha} .{ }^{80}$ Today Brazil ranks as the world's top producer, with a record total yield of over 114 MMT in 2019. Such a massive agrarian expansion progressively tied the country's destiny to both China and Europe. While in the Asian giant the high demand for soya related to human consumption and the production of soya foods and oils, the European demand for Brazilian soya responded to the insatiable appetite of the local meat industry. ${ }^{81}$ By 2018 , overall soya exports to China totalled over 101 MMT, generating revenues of \$US40.64 billion, while in 2019 this fell to 96 MMT for $\$$ US34.78 billion. ${ }^{82}$ Although a recent trade deal with the United States has caused a steep decline in the European Union's total imports of Brazilian soya (from 1.7 MMT in 2017-18 to 1.3 MMT in 2018-19), the European Union still constitutes a second essential business partner. ${ }^{83}$

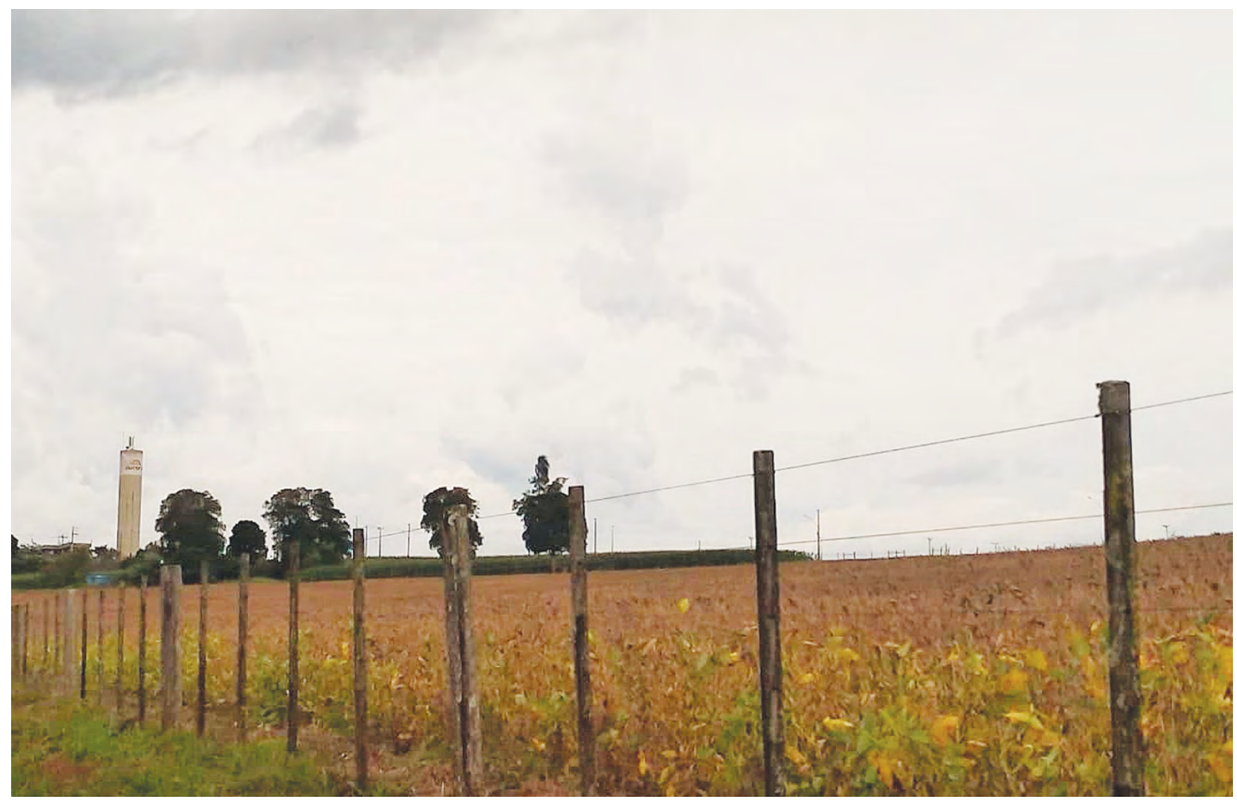

Figure 3: Narratives of the Soyacene: From the fields to the slaughterhouse. A soya field bordering one of the largest chicken slaughterhouses in Latin America. Rural area of Chapecó, Santa Catarina, Brazil, 2019.

Source: Photography by Claiton Marcio da Silva, personal archive.

80 FAO, FAOSTAT (Rome: Statistics Division of FAO), www.fao.org/faostat/en/\#data/QC, accessed 28 July 2021. 81 For the soy-driven economic relationship between Brazil and China, see Maria Eugenia Giraudo, 'Dependent development in South America: China and the soybean nexus', Journal of Agrarian Change 20, no. 1 (2020): 69-78, doi.org/10.1111/joac.12333. For the role of Brazilian soya in the European meat industry, see Annelies Boerema et al., 'Soybean trade: Balancing environmental and socio-economic impacts of an intercontinental market', PLoS ONE 11, no. 5 (2016): e0155222, doi.org/10.1371/journal.pone.0155222.

82 Data from Brazil's National Society for Agriculture (SNA), www.sna.agr.br/exportacoes-do-complexo-sojaem-2019-recuam-450-em-volume-e-1440-em-receita, accessed 28 July 2021.

83 See European Commission, 'United States is Europe's main soya beans supplier with imports up by $112 \%$, Brussels, 7 January 2019, ec.europa.eu/commission/presscorner/detail/en/IP_19_161, accessed 28 July 2021. 
While the increased quantity of exports to the rest of the world has contributed to the overall growth of the national economy, it has increasingly linked the country's fate to the production of soya commodities and their derivates, disincentivising other patterns of economic development. ${ }^{84}$ The choice to turn farming into one of the leading economic sectors also influenced the development agendas of other Southern Cone countries. For example, varieties produced in Brazil by firms such as the EMBRAPA, FT Semente-later bought by Monsanto-disseminated acclimatised transgenic soya crops in other countries such as Mexico, Guatemala, Nicaragua, Bolivia, Colombia and Venezuela, as well as northern portions of Paraguay and Argentina. ${ }^{85}$ Among the Latin American countries in this list, Argentina has the third-highest soya production rate worldwide, with more than 53 MMT produced every year. Soya ranks as the country's second most-produced crop after maize, with five of the leading 45 firms accounting for more than 50 per cent of the total production. This is primarily of transgenic varieties, destined for export to foreign countries, especially Vietnam and Algeria (soya and soya products such as flour and oil) and the Netherlands (mainly biodiesel derived from soy). ${ }^{86}$

Perhaps more surprisingly, a relatively small country like Paraguay currently ranks fifth in global soya production. The country produces almost 10 MMT per year, in between economic giants such as China and India. ${ }^{87}$ Two interdependent factors contributed to farming expansion in Paraguay. These were the concentration of arable lands in a few hands and the centralisation of production policies by Alfredo Stroessner's regime (1954-89). Since the 1970s, several Brazilian families from the country's south-western frontier (Rio Grande do Sul, Santa Catarina and Paraná) have migrated to Paraguay after a political agreement between the two regimes. With the national authorities' blessing, the so-called brasiguaios managed to obtain much farming land, progressively evicting rural inhabitants who did not possess land tenure agreements. Their rise on the farming scene further accelerated during the 1990s, with the introduction of transgenic breeds, today an essential asset of the Paraguayan economy. This process was also related to the emergence of the local meat industry, the country's other primary production sector. ${ }^{88}$ As a result, between the early 1990s and 2003, production almost quadrupled (from 1.17 to 4.5 MMT), covering over 1.5 Mha, more than 80 per cent of the country's total farmed lands. ${ }^{89}$

84 See Alfredo Saad-Filho and Lecio Morais, Brazil: Neoliberalism Versus Democracy (London: Pluto, 2018), doi. org/10.2307/j.ctt1xp3ndh; and Ladislau Dowbor, The Age of Unproductive Capital: New Architectures of Power (Newcastle upon Tyne: Cambridge Scholars, 2019).

85 Terasawa et al. 'FT Sementes', 24.

86 Ministerio de Hacienda [Argentina], Informes de Cadenas de Valor. Oleaginosas: Soja-Sieptiembre 2019, www. argentina.gob.ar/sites/default/files/sspmicro_cadenas_de_valor_soja.pdf, accessed 28 July 2021.

87 AgroLatam, Paraguay volvió al 5 to puesto como productor de soja en el mundo (25 February 2020), www.agrolatam. com/nota/39668-paraguay-volvio-al-5to-puesto-como-productor-de-soja-en-el-mundo, accessed 28 July 2021.

88 Kregg Hetherington, 'La contrarreforma agraria en Paraguay', in Capitalismo: tierra y poder en America Latina (1982-2012), vol. I: Argentina, Brasil, Chile, Paraguay, Uruguay, ed. Guillermo Almeyra et al. (Coyoacán and Buenos Aires: UAM/CLACSO, 2014), 173-214.

89 Luis Maldonado, 'Producción de soja en el Paraguay', Convenio de cooperación ministerio de agricultura y ganaderia de Paraguay, programa regional del FIDA para el Mercosur (January 2005). 
In this context, about 2 per cent of the population owns more than 85 per cent of the country's cultivated lands. ${ }^{90}$ Today, local soya crops are mainly destined for the Latin American market, with Argentina the leading importer of raw soya and sharing the soya flour market with Chile and Peru. ${ }^{91}$

Finally, Bolivia and Uruguay, respectively the tenth- and twelfth-largest world producers, have also increased their agricultural output over the last year, reaching, respectively, about 3 and $2 \mathrm{MMT}^{92}$ Although soya reached Bolivia during the late 1920 s, the country's production only began to increase to industrial levels in the late 1970s and early 1980s with massive investments from the military regime (1964-82). These consisted of introducing varieties from Asia, the United States and Brazil, accompanied by a land reform project financed by the World Bank. The introduction of transgenic varieties has constituted a further leap since 2005, complemented by the elaboration of national biosecurity plans that excluded farmers and consumers from decision-making processes. ${ }^{93}$ In contrast, Uruguay owes its soya production increase to a commercial trade agreement with Taiwan concluded in the mid-1970s, allowing the country to boost production rates to more than 51,000 hectares. The official inception of transgenic varieties was in 1996, after an agreement between the Ministry of Agriculture and Monsanto. Although a national agricultural crisis hindered the expansion of farming during this decade, these biotechnological innovations allowed production volumes to skyrocket during the mid-2000s, turning soya into one of the country's main crops. ${ }^{94}$

Overall, the tropical bonanza of farming generated socioecological transformation in Latin America, especially with the introduction of transgenic crops from the 1990s. As soya crops became an increasingly pervasive force in the most affected bioregions, traditional human communities and native species paid the harshest price. ${ }^{95}$ Thus, while from an eminently scientific perspective the idea of tropical

90 See OXFAM International, Paraguay: El pais donde la soja mata, www.oxfam.org/es/paraguay-el-pais-dondela-soja-mata, accessed 28 July 2021.

91 See Victor Enciso, 'SOJA: Datos, estadísticas y comentarios', Universidad Nacional de Asunción, Facultad de Ciencias Agrarias (FCA-UNA) (March 2020), www.agr.una.py/ecorural/cultivo/soja_marzo_2020.pdf, accessed 28 July 2021.

92 For Bolivia, see the data provided by FUNDACRUZ, 'Producción de Soya en Bolivia alcanza cifra récord y sube la de trigo', www.fundacruz.org.bo/web/noticias/produccion-de-soya-alcanza-cifra-record-y-sube-la-de-trigo, accessed 28 July 2021. On Uruguay, see Ministerio de Ganadería, Agricultura y Pesca, Encuesta Agrícola, Invierno 2020 (August 2020), www.gub.uy/ministerio-ganaderia-agricultura-pesca/sites/ministerio-ganaderia-agriculturapesca/files/2020-08/PUBLICACION_INV2020.pdf, accessed 28 July 2021.

93 Georgina Catacora-Vargas, 'Soya en Bolivia: Producción de oleaginosas y dependencia', in Repúblicas Unidas de la Soja. Realidades de la producción de soya en América del Sur, ed. Javiera Rulli (Asunción: GRR, 2007), 235-51. 94 See Alfredo Blum, Ignacio Narbondo, Gabriel Oyhantcabal, Diego Sancho, Soja transgénica y sus impactos en Uruguay: La nueva colonización (Montevideo: RAP-AL Uruguay, 2008).

95 See Amalia Leguizamón, Seeds of Power. Environmental Injustice and Genetically Modified Soybeans in Argentina (Durham, NC: Duke University Press, 2020), doi.org/10.2307/j.ctv160bv3z. 
agriculture optimistically reiterated the premises of the Green Revolution, it also replicated some of its socio-environmental consequences. ${ }^{96}$

\section{Socioecological impacts}

Although cultivation began more than 5,000 years ago, the emergence of genetically modified and transgenic crops over the last 50 years has led to unprecedented global ecological consequences. In particular, the clearing of native vegetation and forest cover was responsible for the phenomena of water evaporation, soil erosion and compaction, nutrient depletion and intensification of atmospheric pollution. In addition, land grabbing, the urbanisation of rural and wildlife territories, and patterns of unequal wealth redistribution also significantly increased. ${ }^{97}$ As previously indicated, the Southern Cone's most impacted bioregions have been the Brazilian Cerrado, the Gran Chaco plains, Bolivia's Chiquitano forest, the Uruguayan Campos and the Argentinian Pampas. ${ }^{98}$

Since the inception of farming at tropical latitudes, the total land cover has grown from 7 to 55 Mha between 1976 and 2020, a figure presumably destined to increase in the future. ${ }^{99}$ In Brazil, where monoculture already covers over $34 \mathrm{Mha}$, production indexes should reach the production record of 133 MMT in the 2020-21 harvest. ${ }^{100}$ The relentless growth of farming both in volume and in space is likely to exacerbate deforestation rates and illegal arson. ${ }^{101}$ The primary victim of this expansion has been-and will presumably remain — the Cerrado. This bioregion has become one of the world's main breadbaskets since the 1970s while not enjoying the same degree of environmental protection as the Amazon. ${ }^{102}$ Although between 2000 and 2019, monocultures directly linked to deforestation have decreased (from 215,000 to

96 On the socioecological impacts of the Green Revolution, see Vandana Shiva, Monocultures of the Mind: Perspectives on Biodiversity and Biotechnology (London: Zed Books, 1993) and The Violence of the Green Revolution: Third World Agriculture, Ecology and Politics (London: Zed Books, 1991).

97 On some of the most recent causes, see Vivek Voora, Christina Larrea and Steffany Bermudez, Global Market Report: Soybeans (Winnipeg: International Institute for Sustainable Development, 2020): 3, www.iisd.org/system/ files/2020-10/ssi-global-market-report-soybean.pdf, accessed 28 July 2021.

98 WWF, The Growth of Soy.

99 For the latest updates see Xiao-Peng Song, Matthew C. Hansen and Peter Potapov, 'Massive soybean expansion in South America since 2000 and implications for conservation', Nature Sustainability (2021), doi.org/10.1038/ s41893-021-00729-z. Also see Voora et al., Global Market Report: Soybeans, 2.

100 For soya production records in Brazil, see Statista, 'Leading soybean producing countries worldwide from 2012/13 to 2020/21', www.statista.com/statistics/263926/soybean-production-in-selected-countries-since-1980, accessed 28 July 2021. On the increase in soybean farming area, see Song et al., 'Massive soybean expansion in Latin America'.

101 Markus Kröger, 'Field research notes on Amazon deforestation during the Bolsonaro era', Globalizations 17, no. 6 (2020): 1080-3, doi.org/10.1080/14747731.2020.1763063. On increased deforestation indexes in Brazil since 2018, see INPE, TerraBrasilis PRODES (Desmatamento), terrabrasilis.dpi.inpe.br/app/dashboard/ deforestation/biomes/legal_amazon/rates, accessed 28 July 2021.

102 On the historical trajectory of the Cerrado and its environmental history since the 1970s, see Sandro Dutra e Silva, 'Challenging the environmental history of the Cerrado: Science, biodiversity, and politics on the Brazilian agricultural frontier', Historia Ambiental Latinoamericana y Caribeña, HALAC 10, no. 1 (2020): 82-116, doi. org/10.32991/2237-2717.2020v10i1.p82-116. 
73,000 hectares per year), forested areas declined from 134 to 106 Mha between 1985 and 2019. These are mainly linked to the combined expansion of the soya and the livestock industries. ${ }^{103}$ While the former is still proportionally inferior to the latter, its growth rates are undoubtedly superior. Recent remote sensing detection has registered a total increase of the cultivated area in the bioregion from 7.5 to 26 Mha between 1985 and 2019. About 18 Mha of these farmed lands are occupied by monoculture, covering 8.9 per cent of the bioregion's total area.

\section{Landscapes at risk from soy expansion}

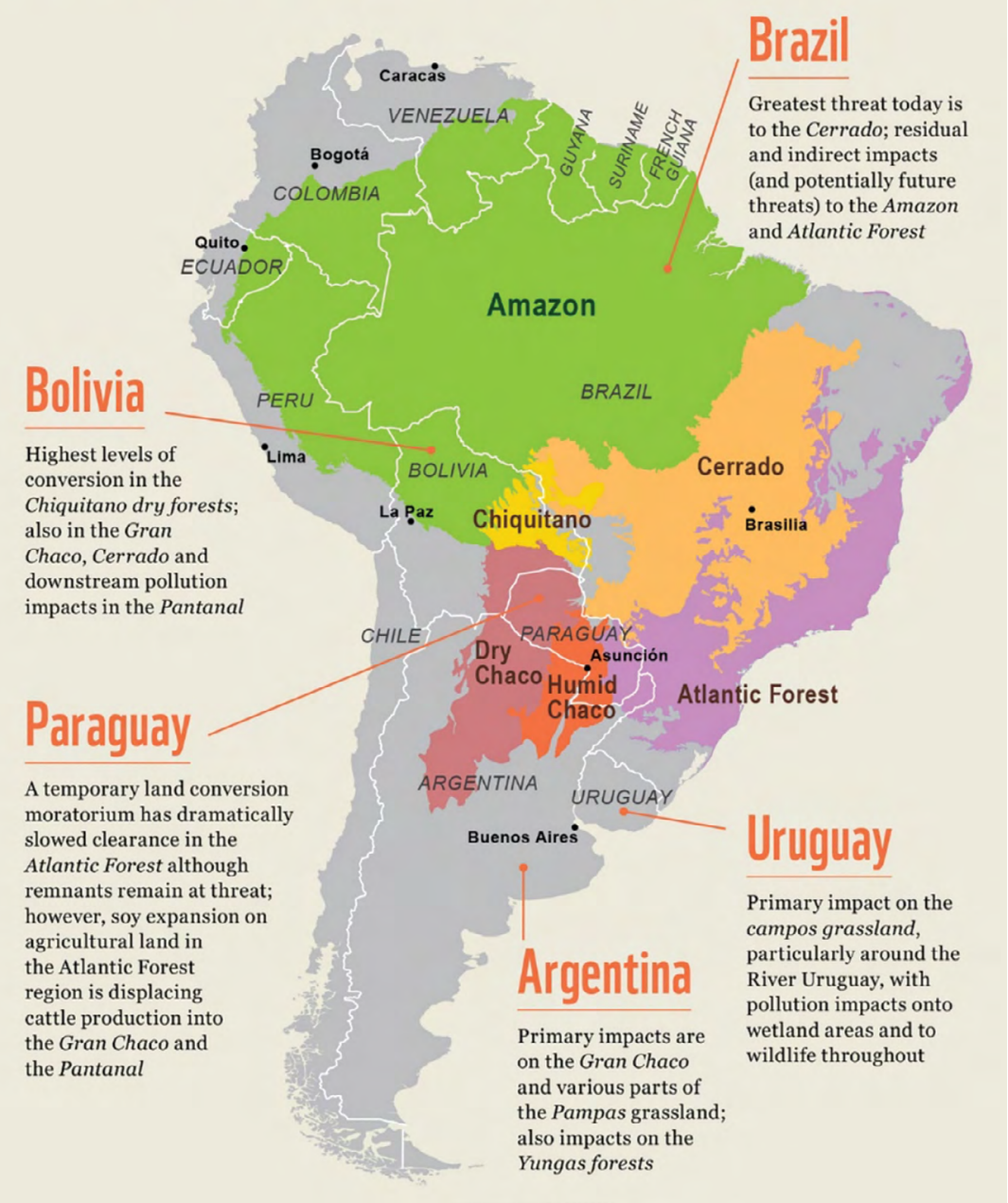

\section{Map 2: The Southern Cone's bioregions impacted by monoculture.}

Source: WWF, www.wwf.org.py/que_hacemos/proyectos/iniciativa_de_transformacion_de_mercados_ mti/la_expansion_soja_en_paraguay, accessed 28 July 2021. 
In contrast, the total pastureland area has increased only from 54 to 61 Mha during this period (see picture below). As a result, between 2001 and 2016, soya farming has been directly linked to 16.6 per cent of forest loss. ${ }^{104}$ Recent projections envision a 5 Mha overall increase of the bioregion's soya cultivated area by 2028-29, mainly at the expense of the surplus native vegetation areas in rural properties already producing soya, especially in the already-mentioned MATOPIBA. ${ }^{105}$

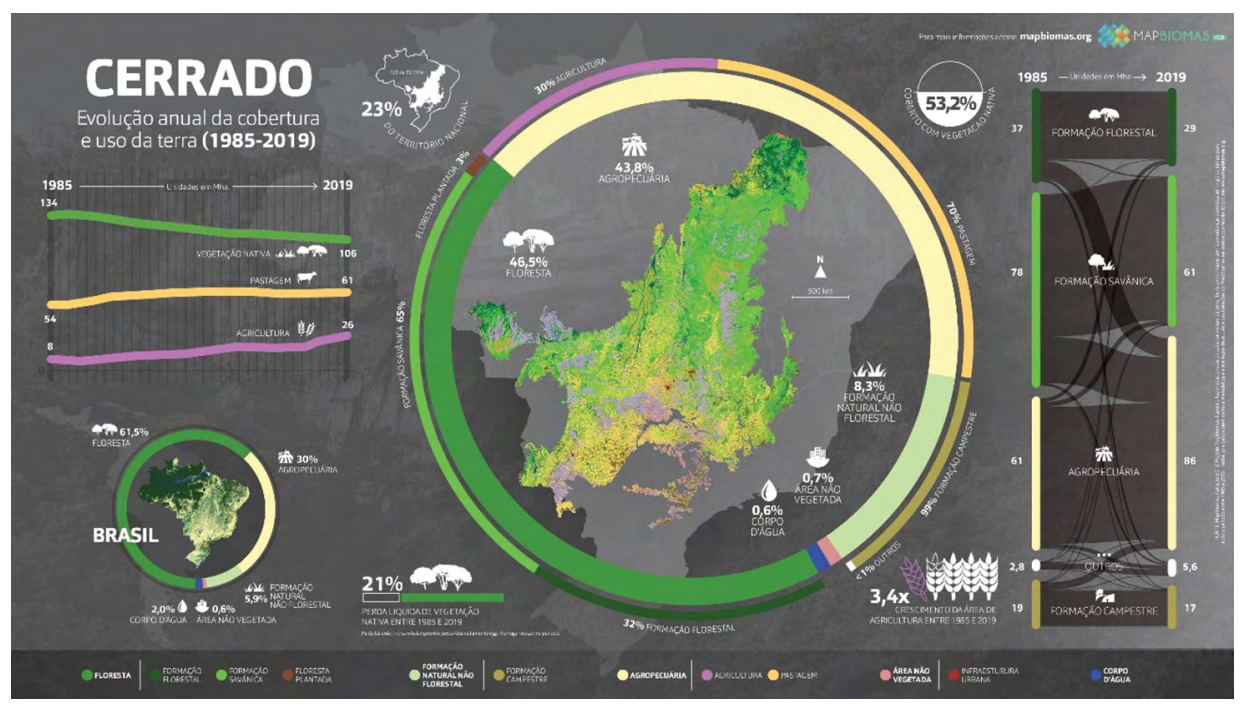

Map 3: The growth of deforestation rates in the Brazilian Cerrado between 1985 and 2019 resulting from the increase in livestock farming and agriculture.

Source: Mapbiomas, mapbiomas-br-site.s3.amazonaws.com/Infograficos/Colecao5/MBI-Infograficocerrado-5.0-BR.jpg, accessed 27 July 2021.

In the Brazilian Amazon, although a soya moratorium approved in 2006 formally reduced deforestation rates linked to farming, it also promoted the progressive expansion of the industrial livestock frontier, especially along the border with the Cerrado (the so-called spillover effect). ${ }^{106}$ As displayed below, between 1985 and 2019, livestock farming more than tripled (from 16 to 59 Mha), accompanied by the (sometimes illegal) increased cultivation (from 0 to $6 \mathrm{Mha}$ ). This process is indissolubly associated with increased illegal forest clearing, considering

104 See Song et al., 'Massive soybean expansion in Latin America'.

105 ABIOVE, Geospatial Analysis of Soy Crop in the Cerrado, 3.

106 On the positive effects of the moratorium on the Amazon, see Daniel Nepstad et al., 'Slowing Amazon deforestation through public policy and interventions in beef and soy supply chains', Science 344, no. 6188 (2014): 1118-23, doi.org/10.1126/science.1248525; and Alexandra Tyukavina, et al., 'Types and rates of forest disturbance in Brazilian Legal Amazon, 2000-2013', Science Advances 3, no. 4 (2017): e1601047, doi.org/10.1126/ sciadv.1601047. On the spillover effect, see Nikolas Kuschnig, Jesus Crespo Cuaresma and Tamás Krisztin, 'Unveiling drivers of deforestation: Evidence from the Brazilian Amazon', Ecological Economic Papers 32 (Vienna: WU Vienna University of Economics and Business, 2019); and Raoni Rajão et al., 'The rotten apples of Brazil's agribusiness', Science 369, no. 6501 (2020): 246-8, doi.org/10.1126/science.aba6646. 
that 6 per cent of the total forest loss between 2001 and 2016 is related to soya farming. ${ }^{107}$ In this context of increased anthropogenic pressures, the cultivated area has increased more than tenfold over the last 20 years-from 0.4 to $4.6 \mathrm{Mha}$ - the most rapid expansion rate in all Latin America. ${ }^{108}$

Overall, Brazil lost an average of 3.78 Mha of protected areas per year between 1990 and 2000. The figure reached an average peak of $3.95 \mathrm{Mha}$ in the following decade and later declined to 1.50 Mha during the 2010s. ${ }^{109}$ Such data display an interesting paradox: although increased soya farming productivity has exercised an overall positive impact on deforestation, growing market demands are likely to continue fostering the expansion of soya monocultures in the near future, mainly at the expense of native forest cover. Globally, between 1961 and 2018, crop yields have not been able to keep up with production, the former increasing by 150 per cent, while the latter increased by 1,200 per cent. As a result, the total area destined for soya farming more than quadrupled, despite technological advancements and ambitious agrarian plans. Brazil is no exception to the rule: although soya yields have doubled since 1980, production has increased by 680 per cent, tripling the total land use. ${ }^{110}$

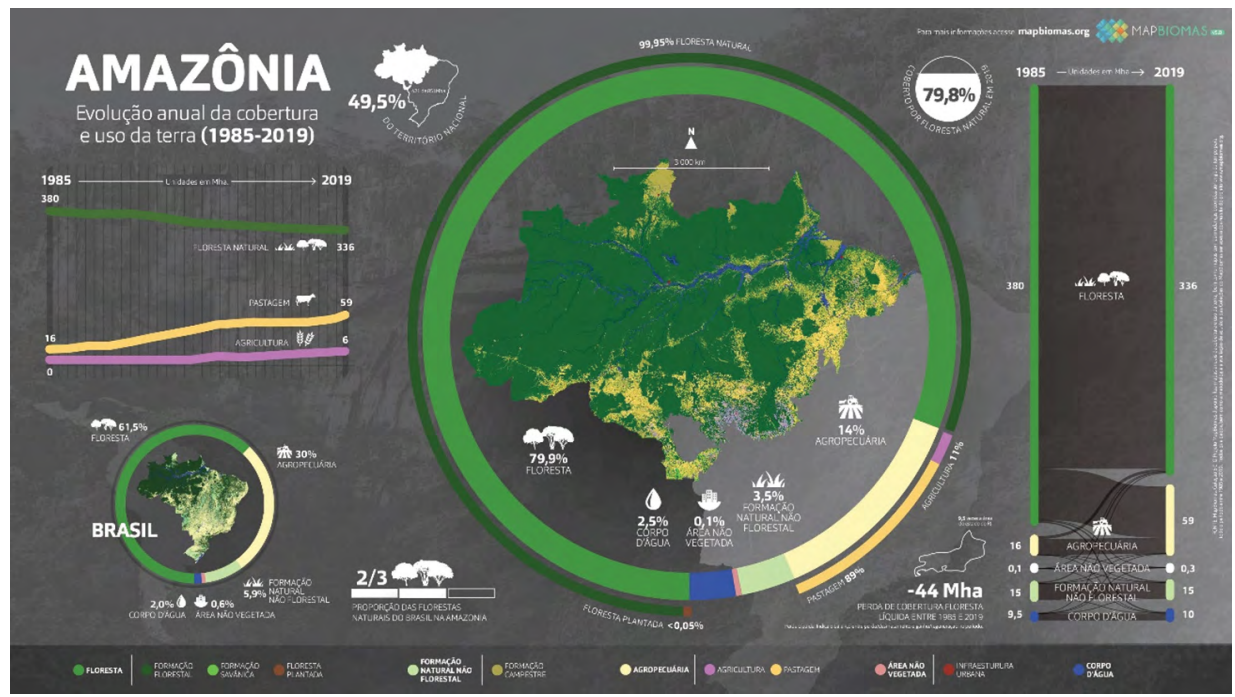

Map 4: The massive increase of the livestock industry in the Amazon between 1985 and 2019, accompanied by the (sometimes illegal) rise of cultivation.

Source: Mapbiomas, mapbiomas-br-site.s3.amazonaws.com/Infograficos/Colecao5/MBI-Infograficoamazonia-5.0-BR.jpg, accessed 27 July 2021.

107 On illegal deforestation see Claire Asher, 'Brazil soy trade linked to widespread feforestation, carbon emissions', Monogabay, 3 April 2019, news.mongabay.com/2019/04/brazil-soy-trade-linked-to-widespread-deforestationcarbon-emissions, accessed 28 July 2021. On its relationship to soya farming, see Song et al., 'Massive soybean expansion in Latin America'.

108 Song et al., 'Massive soybean expansion in Latin America'.

109 FAO, Global Forest Resources Assessment 2020: Main Report (Rome: FAO, 2020), 18, doi.org/10.4060/ ca9825en.

110 Ritchie, 'Soy'. 
As for Argentina, although the country registered a minor deforestation rate compared to Brazil, in 2018 alone it lost 112,766 hectares of forest, 40,965 of which were classified as protected wildlife territories. Overall, between 1990 and 2015, the country lost 7.6 Mha of forest to soya monoculture. This phenomenon has particularly affected the northern Pampas bioregion-12.2 per cent of forest loss between 2001 and 2016 associated with farming — and to a lesser extent, the Gran Chaco Plains (of which, more below). ${ }^{111}$ By the 2012-13 harvest, the total planted area had reached a record figure of almost 19.5 Mha, a number that declined to less than 17 Mha by the time of the 2018-19 harvest. However, such a decrease has not determined a slowdown in production rates: during 2012-13, total production reached almost 50 MMT, while in 2018-19, it surpassed 55 MMT due to increased productivity (from 2.54 MMT per Mha in 2013 to 3.26 in 2019). ${ }^{112}$

The expansion of farming has also resulted in the progressive concentration of arable land (either owned or rented) in the hands of mega-companies, both national (e.g. Los Gorbo, El Tejar, MSU) and international ones, such as Cresud and Adecoagro. ${ }^{113}$ These land concentrations have become notorious as the 'new enclosures', given the systematic processes of rural violence towards both rural and indigenous communities that have characterised them. Moreover, although transgenic crops have consistently improved production indexes, glyphosate fumigations have also led to dramatic health consequences for the rural communities hit by the pesticide. These include various respiratory disorders, cancer, foetal malformations and premature abortions. ${ }^{114}$

\footnotetext{
111 On the relationship between soya monocultures and deforestation rates in the Pampas, see Song et al., 'Massive soybean expansion in Latin America'.

112 See Sistema de Información Simplificado Agrícola (SISA), Soja 2018.2019 (Buenos Aires: Ministerio de Agricultura, Ganadería y Pesca, 2019): 7, www.argentina.gob.ar/sites/default/files/informe_soja_0.pdf, accessed 28 July 2021; also see Song et al., 'Massive soybean expansion in Latin America'.

113 See Greenpeace, Deforestación en el norte de Argentina-informe anual 2018 (Buenos Aires, Greenpeace Argentina, 2019), greenpeace.org.ar/pdf/Deforestacion-norte-Argentina-Informe-Anual-2018.pdf, accessed 28 July 2021; also see Sebastían Gómez Lende and Guillermo Velázquez, 'Soybean agribusiness in Argentina (19902015): Socio-Economic, eerritorial, environmental, and political implications', in Agricultural Value Chain, ed. Gokhan Egilmez (London: IntechOpen, 2018), 117-36.

114 Katarzyna Olga Beilin and Sainath Surynarayanan, 'The war between amaranth and soy: Interspecies resistance to transgenic soy agriculture in Argentina', Environmental Humanities 9, no. 2 (2017): 204-29, doi. org/10.1215/22011919-4215211.
} 


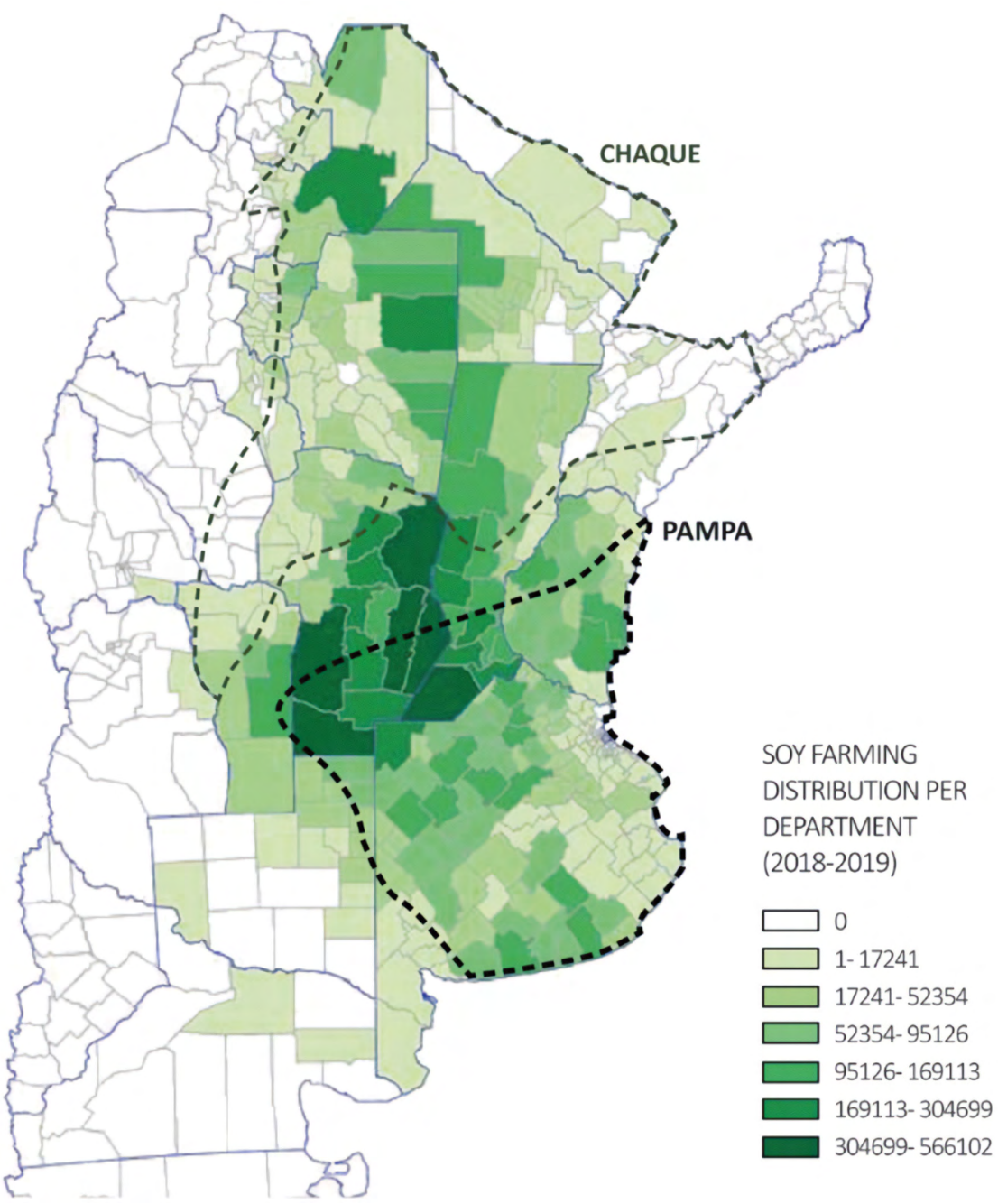

Map 5: Soya producing provinces in Argentina, with concentration peaks between the Pampa and a small land stripe of the Espinal savannah bioregions (over $6 \mathrm{Mha}$ ), and the Gran Chaco districts (between 0.5 and $1 \mathrm{Mha}$ ).

Source: Sistema de Información Simplificado Agrícola (SISA), Ministerio de Agricultura, Ganadería y Pesca, Presidencia de la Nación. Available at www.argentina.gob.ar/sites/default/files/informe_soja_0. pdf, accessed 12 October 2021.

Argentina's tiny neighbour, Uruguay, has also registered the socio-environmental impacts of extensive monoculture. The country's most affected territory is the temperate grassland bioregion known as Campos. Here, the expansion of monoculture has accelerated soil erosion and hydrological disorders. Such a process has gone hand in hand with a steep increase in land prices, the demise of traditional agricultural 
systems and the disenfranchisement of several rural communities. ${ }^{115}$ Similarly, according to recent estimates by the UN Food and Agriculture Organization (FAO), Paraguay and Bolivia occupy the sixth and ninth positions, respectively, in the top 10 countries for an average annual net loss of forest area in 2010-20. ${ }^{116}$ The most remarkable numbers concerning farming are those of Paraguay, where soya monocultures currently cover about 80 per cent of the overall arable lands, reaching over 3.6 Mha by the 2020 harvest. ${ }^{117}$ This process has heavily damaged the eastern Atlantic rainforest region, which quickly shrank to only 13 per cent of its original size. ${ }^{118}$ According to 2018 estimates by the US National Aeronautics and Space Administration (NASA), Paraguay presents one of the highest deforestation rates in Latin America, with almost 4.5 Mha deforested only between 1987 and 2012, an area that has probably further increased over the last years with the expansion of local agribusinesses. ${ }^{119}$ With over 1.2 Mha covered by soya monocultures, Bolivia is also experiencing a steep growth in the land area occupied by farming, more than 4 per cent every year. ${ }^{120}$ Its most affected tropical bioregions are the Gran Chaco Plains and the Chiquitano Forest. The first consists of a lowland hot and semiarid sedimentary plain covering almost $800,000 \mathrm{~km}^{2}$ between northern Argentina, western Paraguay, eastern Bolivia and parts of the Brazilian states of Mato Grosso and Mato Grosso do Sul. The second one is a dry broadleaf dry forest ecoregion comprising the Gran Chaco and Pantanal bioregions. Its area accounts for more than 230,000 $\mathrm{km}^{2}$ encompassing the Bolivian Andes and part of the Brazilian states of Mato Grosso and Rondônia, taking its name from the indigenous people who have inhabited the region for millennia.

Although together they constitute one of the most significant continuous areas of native vegetation in South America, these two delicate bioregions have experienced a steep increase in unregulated intensive farming activities since the early 2000s. Over-farming is responsible for the highest conversion rates of local forests to agriculture. Almost a third of these activities are directly linked to farming, leading to a significant reduction in native vegetation and accelerating species extinction

115 REDES Amigos de la Tierra Uruguay, Impactos del cultivo de soja en Uruguay. Cambios en el manejo de la tierra y en el uso de agroquimicos (Montevideo, 2011). Available at www.redes.org.uy/2011/12/19/impactos-del-cultivode-soja-en-uruguay, accessed 28 July 2021.

116 FAO, Global Forest, 18.

117 Ministerio de Agricultura y Ganadería, 'Síntesis Estadísticas Año Agrícola 2019/2020', September 2020, www.mag.gov.py/Censo/SINTESIS\%20ESTADISTICAS\%202019-2020.pdf, accessed 28 July 2021.

118 WWF, 'La expansión de la soja en Paraguay', www.wwf.org.py/que_hacemos/proyectos/iniciativa_de_ transformacion_de_mercados_mti/la_expansion_soja_en_paraguay, accessed 28 July 2021.

119 NASA Earth Observatory, Deforestation in Paraguay, earthobservatory.nasa.gov/images/92078/deforestationin-paraguay, accessed 28 July 2021.

120 See FUNDACRUZ, 'Producción de Soya en Bolivia'. 
risks. ${ }^{121}$ Overall, between 2000 and 2016, farming has been linked to forest losses of 10.5 and 18.8 per cent in the Chaco and Chiquitano forests, respectively. ${ }^{122}$ Biodiversity loss has also hindered the absorption of heavy rain volumes, thus accelerating the risks of hydro-ecological disorders such as floods, landslides and soil erosion. ${ }^{123}$ Equally important, this process is threatening the livelihoods of rural and indigenous people, increasing land prices, impairing access to local resources and incrementally worsening poverty. ${ }^{124}$ Although local communities have relentlessly opposed clearance policies and demanded land rights, recent episodes of illegal arson and increasing deforestation rates paint an uncertain picture of future conservation scenarios. ${ }^{125}$

\section{The Soyacene in global environmental history}

The tropical soya bean farming bonanza began with the agricultural expansion of this resilient and versatile grain in the Latin American tropics, transforming it into a global commodity like petrol, palm oil, cotton or maize. Today farming plays a ubiquitous role in industrial processes. Several nations and the international market heavily rely on its nutrients and derived products in different forms and on different scales. As this article has demonstrated, the global expansion of soya emerged from the intersection of national and international processes and long-term scientific experiments. The Soyacene began to blossom during the late 1960s in Latin America, imposing different agricultural management and territorial control regimes upon rural communities and ultimately modifying entire ecological bioregions. The versatility of this leguminous grain, united with

\footnotetext{
121 On deforestation in these two bioregions, see Yann le Polain de Waroux et al., 'Land-use policies and corporate investments in agriculture in the Gran Chaco and Chiquitano', Proceedings of the National Academy of Sciences of the United States of America 113, no. 15 (2016): 4021-6, doi.org/10.1073/pnas.1602646113; on the environmental consequences of deforestation, see Verena Fehlenberga et al., 'The role of soybean production as an underlying driver of deforestation in the South American Chaco', Global Environmental Change 45 (2017): 24-34, doi.org/10.1016/j. gloenvcha.2017.05.001; and Jordan Graesser, Navin Ramankutty and Oliver T. Coomes, 'Increasing expansion of large-scale crop production onto deforested land in sub-Andean South America', Environmental Research Letters 13 (2018): 084021, doi.org/10.1088/1748-9326/aad5bf.

122 Song et al., 'Massive Soybean Expansion in Latin America'.

123 See Druetta, 'La deforestación ilegal'.

124 See Yann le Polain de Waroux et al., 'Rents, actors and the expansion of commodity fontiers in the Gran Chaco', Annals of the American Association of Geographers 108, no. 1 (2018): 204-25, doi.org/10.1080/246944 52.2017.1360761; César J. Pérez and Carl A Smith, 'Indigenous knowledge systems and conservation of settled territories in the Bolivian Amazon', Sustainability 11, no. 21 (2019): 6099, doi.org/10.3390/su11216099.

125 On conservation issues in the Gran Chaco, see Maria Laura Carranza et al., 'Measuring forest fragmentation using multitemporal forest cover maps: Forest loss and spatial pattern analysis in the Gran Chaco, Central Argentina', Landscape and Urban Planning 143 (2015): 238-47, doi.org/10.1016/j.landurbplan.2015.08.006; on the Ciquitano, see Michael J. Dockry and Nancy Langston, 'Indigenous protest and the roots of sustainable forestry in Bolivia', Environmental History 24, no. 1 (2019): 52-77, doi.org/10.1093/envhis/emy090. On arson and illegal forestry, see Alfredo Romero-Muñoz et al., 'Fires scorching Bolivia’s Chiquitano forest', Science Magazine, 29 November 2019, www.sciencemagazinedigital.org/sciencemagazine/29_november_2019/MobilePagedArticle. action?articleId=1541348\#articleId1541348, accessed 28 July 2021.
} 
mechanised agricultural techniques, global market demands and ambitious national developmental plans, allowed soya cultivation to expand in several tropical regions of the world. Over the last decades, farming has also gained momentum in India's central and southern areas and sub-Saharan Africa. While the crop has improved local nutrition regimes, the prospective introduction of transgenic crops has generated concerns. These include the resilience of small farming enterprises, biodiversity loss in already endangered ecosystems, coastal erosion and the destruction of traditional fisheries. ${ }^{126}$ This scenario will likely continue to worsen in future decades without appropriate regulation. Although enhanced productivity is increasingly allowing the maximisation of production indexes while sparing land area, farming currently constitutes a significant cause of environmental devastation - and by extension, economic threats and social conflicts. According to a 2013 report drafted by the European Union, soya farming is linked to 19 per cent of total global deforestation rates, accounting for half of the embodied imported products. ${ }^{127}$

This article has attempted to assess the singular historical trajectory of this grain at tropical latitudes, analysing its inception in conjunction with global transformations in market demand, production and agricultural industrialisation. Equally important, it has described the biological singularity of soya and its endemic qualities-most notably its capacity to produce proteins and fix nitrogen-that allowed it to gain historical momentum in global agriculture compared to other crops. These unique characteristics stimulated scientists, entrepreneurs and policymakers to seek viable solutions to guarantee large-scale expansion in tropical climates, thus expanding the world's agricultural frontier. ${ }^{128}$ While both rural and economic historians are increasingly investigating the complex historical dynamics of this grain, this article has also attempted to complement these narratives by describing the local and

126 On soya production index in India, see Abayomi Jegede, 'Top 10 largest soybean producing states in India', The Daily Records, 2 January 2019, www.thedailyrecords.com/2018-2019-2020-2021/world-famous-top-10-list/ india/largest-soybean-producing-states-india/18401, accessed 28 July 2021. For a short history of soybean in India, see B. U. Dupare et al., 'Origin, domestication, introduction and success of soybean in India', Asian Agri-History 12, no. 3 (2008): 179-95; and Dinesh K. Agarwal et al., 'Soybean: Introduction, improvement, and utilization in India_problems and prospects', Agricultural Research 2 (2013): 293-300, doi.org/10.1007/s40003-013-0088-0. On soya production rates in Africa, see Christine H. Foyer, et al., 'Modelling predicts that soybean is poised to dominate crop production across Africa', Plant, Cell \& Environment 42, no. 1 (2018): 1-13, doi.org/10.1111/ pce.13466. For an historical overview of soybean farming in Africa, see Dalia Mohamedkheir Khojelyab et al., 'History, current status, and prospects of soybean production and research in Sub-Saharan Africa', The Crop Journal 6, no. 3 (2018): 226-35, doi.org/10.1016/j.cj.2018.03.006. On ecological concerns, see Subhojit Goswami, 'Resisting GM crops is our responsibility: expert', DownToEarth, 28 August 2017, www.downtoearth.org.in/news/ agriculture/resisting-gm-crops-is-our-responsibility-expert-57830, accessed 28 July 2021; Richard Harnisch, ed., Sustainable Consumption for Biodiversity and Ecosystem Services (Bonn: Federal Agency for Nature Conservation, 2019); Foday Bojang and Ada Ndeso-Atanga, 'The relevance of mangrove forests to African fisheries, wildlife and water resources', Nature \& Faune 24, no. 1 (2009).

127 European Commission, 'The impact of EU consumption on deforestation: Comprehensive analysis of the impact of EU consumption on deforestation', Technical Report (2013), 21, ec.europa.eu/environment/forests/ pdf/1.\%20Report\%20analysis\%20of\%20impact.pdf, accessed 28 July 2021.

128 Marcel Mazoyer and Laurence Roudart, A History of World Agriculture: From the Neolithic Age to the Current Crisis (New York: Monthly Review Press, 2006). 
global socioecological consequences associated with the 'tropicalisation' of soya. ${ }^{129}$ Deforestation, biodiversity loss, water contamination and the marginalisation of rural and indigenous communities are part and parcel of the sombre scenario linked to the relentless expansion of soya on the world stage.

On the other hand, this 'magic' bean's capacity to adapt to tropical latitudeswith the aid of biotechnological applications - has led to global transformations in nutrition regimes. Altogether, these factors constitute an essential parcel of the anthropogenic process known as the Great Acceleration, a 70-year period in which human beings have dramatically increased their influence on the environmental balance of the eco-biosphere, laying the foundations for the geological hypothesis of the Anthropocene. Both in the colder latitudes of the Global North and the warmer ones of the Global South, the Great Acceleration wore the garments of massive urbanisation, climate change, deforestation, energy transition and agricultural mechanisation. ${ }^{130}$ From the 1970 s, several tropical and subtropical bioregions of the Latin American Southern Cone began to embrace farming, inaugurating the beginning of the Soyacene, a phenomenon indissolubly related to the agricultural and ecological transformations brought by the Great Acceleration.

As international market demands intersected with ambitious national plans, they transformed large portions of bioregions into monocultures. These became one of the constitutive features of the Great Acceleration in several countries of the Global South-living evidence of the Anthropocene. While each country specialised in different productive sectors from the 1970s, large-scale soya farming emerged as a common denominator. As soya expanded in these hot, damp climates, it brought economic growth and improved nutrition regimes. However, it also created the ecological threats and social issues that today characterise the Soyacene. With the world's population projected to increase by more than 2 billion in the coming three decades, there is no doubt that the tropical bonanza of soya will necessarily continue for years to come, fuelled by demographic growth and international market demands. ${ }^{131}$ Future production should increase by 50 per cent by the middle of the twenty-first century, much of it presumably in South America, requiring an additional area of at least 20 Mha. ${ }^{132}$ Despite a significant increase in productivity, the Soyacene is undoubtedly here to stay, especially in the Latin American Southern

129 For the latest examples of agrarian investigations of soya, see Herbert S. Klein and Francisco Vidal Luna, Feeding the World: Brazil's Transformation into a Modern Agricultural Economy (Cambridge: Cambridge University Press, 2019); also see Matthew Roth, Magic Bean: The Rise of Soy in America (Lawrence, KS: University Press of Kansas, 2018), doi.org/10.2307/j.ctv1nhq2c; for economic analyses on soybeans, see Ernst Langthaler, 'The soy paradox: The Western nutrition transition revisited 1950-2010', Global Environment 11, no. 1 (2018): 79-104, doi.org/10.3197/ge.2018.110105.

$130 \mathrm{McNeill}$ and Engelke, The Great Acceleration.

131 See the projections of the United Nations Department of Economic and Social Affairs at www.un.org/ development/desa/en/news/population/world-population-prospects-2019.html, accessed 28 July 2021.

132 See Nikos Alexandratos and Jelle Bruinsma, World Agriculture Towards 2030/2050: The 2012 Revision (Rome:

FAO, 2012), www.fao.org/3/ap106e/ap106e.pdf, accessed 28 July 2021. 
Cone bioregions where it came into being. What remains unclear is whether the social and ecological costs will fatally exceed its benefits, or if a combination of social and political action will manage to reshape them according to more socially equitable and ecologically sustainable standards.

\section{Acknowledgements}

The authors wish to thank IREH editor-in-chief James Beattie for his support along the way. A special thank goes to Sandro Dutra e Silva for enthusiastically embracing the Soyacene as a proposed historical concept, providing helpful comments and insights about the Brazilian Cerrado. Vitória Fank Spohr adapted maps 1, 2 and 5 following our indications. In addition, two anonymous reviewers provided valuable comments and insights to strengthen the article's content further. During this research, Claiton Marcio da Silva received a productivity research fellowship (Processo 307082/2019-9) from the Brazilian National Council for Scientific and Technological Development (CNPq), while Claudio de Majo received funding from the Leibniz Institute of European History (IEG) and the Amerika-Institut (LMU Munich). 
This text is taken from International Review of Environmental History, Volume 7 , Issue 2, 2021, edited by James Beattie, published 2021 by ANU Press,

The Australian National University, Canberra, Australia.

doi.org/10.22459/IREH.07.02.2021.03 